Check for updates

Cite this: RSC Adv., 2021, 11, 35918

\section{A comparative assessment of in vitro cytotoxic activity and phytochemical profiling of Andrographis nallamalayana J.L.Ellis and Andrographis paniculata (Burm. f.) Nees using UPLC-QTOF-MS/MS approach $\dagger$}

\author{
Narender Goel, $\neq^{\text {ad }}$ Rahul L. Gajbhiye, $\$^{\mathrm{a}}$ Moumita Saha, $\ddagger^{\mathrm{b}}$ Chennuru Nagendra, ${ }^{\mathrm{c}}$ \\ Araveeti Madhusudhana Reddy, ${ }^{c}$ V. Ravichandiran, ${ }^{a}$ Krishna Das Saha (D) ${ }^{b}$ \\ and Parasuraman Jaisankar (D)*d
}

\begin{abstract}
Andrographis paniculata (Burm. f.) Nees and Andrographis nallamalayana J.L.Ellis have traditionally been used to treat various ailments such as mouth ulcers, intermittent fever, inflammation, snake bite. This study compares the comparative in vitro cytotoxic activity, and phytochemical profiling of methanol extract of A. nallamalayana (ANM) and A. paniculata (APM). UPLC-ESI-QTOF-MS/MS analysis has been performed. The cytotoxic activity of crude methanol extracts were evaluated against three different cancer cell lines (HCT 116, HepG2, and A549 cell line). Both plants' extract exhibited significant cytotoxic activity against tested cell lines in a dose-dependent manner. IC $C_{50}$ of ANM and APM in HCT 116 cell was $11.71 \pm 2.48 \mu \mathrm{g} \mathrm{ml}^{-1}$ and $45.32 \pm 0.86 \mu \mathrm{g} \mathrm{ml}^{-1}$ and in HepG2 cell line was $15.65 \pm 2.25 \mu \mathrm{g} \mathrm{ml}^{-1}$ and $60.32 \pm 1.05 \mu \mathrm{g} \mathrm{ml}^{-1}$ respectively. Cytotoxicity of these two extracts was comparatively similar in A549 cells. ANM induced cytotoxicity involved programmed cell death, externalisation of phosphatidylserine, ROS generation, up-regulation and down-regulation of major apoptotic markers. HRMS analysis of ANM and APM resulted in the identification of 59 and 42 compounds, respectively. Further, using the MS/MS fragmentation approach, 20 compounds, of which 18 compounds were identified for the first time from ANM, which belongs to phenolic acids, flavonoids, and their glycosides. Three known compounds, echioidinin, skullcapflavone I and 5,2',6'-trihydroxy-7-methoxyflavone 2'-O- $\beta$-Dglucopyranoside, were isolated from $A$. nallamalayana and their crystal structures were reported for the first time. Subsequently, seven major compounds were identified in A. nallamalayana by direct comparison (retention time and UV-spectra) with authentic commercial standards and isolated compounds using HPLCUV analysis. The cytotoxicity of phytochemicals from both the plants using in silico tools also justify their in vitro cytotoxic activity. It is the first report on the comparative characterisation of phytochemicals present in the methanolic extract of both the species of Andrographis, along with the cytotoxic activity of $A$. nallamalayana.
\end{abstract}

Received 10th October 2021 Accepted 18th October 2021

DOI: $10.1039 / \mathrm{d} 1 \mathrm{ra} 07496 \mathrm{~b}$

rsc.li/rsc-advances difference, there is a drastic variety of medicinal plants, and they have been used for different ailments. ${ }^{1}$ With a large variety of plants, Acanthaceae is considered one of the top nine families of medicinal plants, including 2500 species and 250 genera. ${ }^{2}$ One of the important genera of Acanthaceae is Andrographis, which is widely used in the Indian medicine system.

Mullick Road, Kolkata-700032, India. E-mail: jaisankar@iicb.res.in; Tel: +91-3324995-790/774

$\dagger$ Electronic supplementary information (ESI) available. CCDC 2072153, 2072155 and 2072714. For ESI and crystallographic data in CIF or other electronic format see DOI: $10.1039 / \mathrm{d} 1 \mathrm{ra} 07496 \mathrm{~b}$

$\ddagger$ Authors contributed equally to this work.

${ }^{a}$ Department of Natural Products, National Institute of Pharmaceutical Education
and Research (NIPER-Kolkata), Chunilal Bhawan, 168, Maniktala Main Road,
700054, Kolkata, India
${ }^{b}$ Cancer Biology and Inflammatory Disorder Division, CSIR-Indian Institute of
Chemical Biology, 4, Raja S. C. Mullick Road, Jadavpur, Kolkata-700032, India
${ }^{c}$ Department of Botany, Yogi Vemana University, Vemanapuram, Kadapa, Andhra
Pradesh 516005, India
${ }^{d}$ Laboratory of Catalysis and Chemical Biology, Department of Organic and
Medicinal Chemistry, CSIR-Indian Institute of Chemical Biology, 4 Raja S. C. 
Among several other members of the Andrographis genus, Andrographis paniculata (Burm. f.) Nees is an essential and wellstudied medicinal plant. It has been used widely as a traditional medicine in India, China, Thailand and other Southeast Asian countries to treat various diseases such as wounds, malaria, jaundice, gonorrhoea, skin diseases, and boils. ${ }^{3-6}$ Various pharmacological studies have stated the importance of $A$. paniculata for treating diseases such as inflammation, influenza, diabetes, hypertension, ulcer. ${ }^{7-10}$ Various groups have also evaluated the in vitro and in vivo antitumor and immunomodulatory activity of $A$. paniculata. ${ }^{11-14}$ More than 55 ent-labdane diterpenoids, 30 flavonoids, eight quinic acids, four xanthones, and five rare noriridoids have been isolated from $A$. paniculata. ${ }^{15-19}$

Andrographis nallamalayana J.L.Ellis, commonly known as 'Kachugadda' is a lesser-known species of the Andrographis genus, an endemic procumbent herb distributed only in the core area of Nallamala Hills, Eastern Ghats, Andhra Pradesh, India. A. nallamalayana blended with Acrocephalus indicus and Acrocephalus hispidus, which is then boiled and further mixed with a lime pinch, the decoction is generally given orally for mouth ulcers by the tribals of Nallamala Hills, Eastern Ghats, Andhra Pradesh, India. ${ }^{\mathbf{2 0 , 2 1}}$ Fresh root paste of $A$. nallamalayana mixed with leaves juice of Becium filamentosum, is also used in many regions as an antidote for snakebite. ${ }^{21} 5 \mathrm{~g}$ root of each $A$. nallamalayana and $A$. indicus ground, decoction prepared and given orally from the third day of delivery/menses for four days and also for the treatment of leucorrhoea by the Adivasi in the Eastern Ghats of Andhra Pradesh, India. ${ }^{22}$ Recent studies have shown that methanolic extract of $A$. nallamalayana used for antimicrobial, ${ }^{23}$ anti-psoriatic, ${ }^{24}$ anti-candidal ${ }^{25}$ and antiproliferative, anti-inflammatory and pro-apoptotic activities. ${ }^{26}$ The preliminary phytochemical screening demonstrated the presence of flavonoids, alkaloids, phenols, steroids and triterpenoids. Parlapally et al. using GC/MS and LC/MS analysis, reported the presence of chromones, flavones/flavanones and their glycosides. ${ }^{24}$ UHPLC-ESI-QTOF-MS techniques have been used as a powerful analytical tool because of their high accuracy and sensitivity in characterising various complex natural products materials. The attained accurate mass spectra of elemental composition and tandem mass spectrometry (MS/MS) spectra allow detection and identification of the individual chemical structures. ${ }^{27}$ The novel drug development is a very complicated and time-consuming process. However, nearly $40 \%$ of the drug applicants failed due to unanticipated toxicity and adverse drug reactions. For the preliminary stage of drug development, computer-aided in silico strategies have become vital as they support more cost-effectively. ${ }^{28-30}$ For the development of bioactive phytoconstituents, the global research scenario recommends using virtual screening methods/technology. ${ }^{31}$ Prediction of possible pharmacological activity via in silico approach is based on the structure-activity relationship, which is usually correlated with the experimental data. ${ }^{32,33}$ In silico studies combined with biological activities would reduce the time and cost for the development of novel drugs. A. paniculata is a mine for bitter compounds for medicinal purposes, but the scarcity of literature studies on A. nallamalayana related to phytochemical profiling and biological evaluation paves the way for this study. In this study, an attempt was made to determine the comparative in vitro cytotoxic activity and the phytochemical profiling of $A$. nallamalayana and A. paniculata and in silico prediction of cytotoxic activity of identified compounds in order to validate the ethnopharmacological use of these plants in India. To the best of our knowledge, it was the first report on the comparative characterisation of phytochemicals present in the methanolic extract of both the species of Andrographis, along with the cytotoxic activity of $A$. nallamalayana.

\section{Materials and methods}

\subsection{Chemicals and reagents}

Water, methanol and acetonitrile (LC-MS grade) were purchased from J. T. Baker (USA). MilliQ water (Millipore Elix 10 model, USA) was used for biological work. The additives, formic acid and acetic acid (LC-MS grade) were purchased from SigmaAldrich Co. (St. Louis, MO, USA). Hispidulin 7-glucoside (cat. no. SML2157), oroxylin A (cat. no. PHL82615), chlorogenic acid (cat. no. C3878), 4-di-O-caffeoylquinic acid (cat. no. SMB00224), quercetin, gallic acid standards and Folin-Ciocalteu reagents were purchased from Sigma-Aldrich Co. (St. Louis, MO, USA). Trypsin, Fetal Bovine Serum (FBS), ethylenediaminetetraacetic acid (EDTA), penicillin-streptomycin-neomycin (PSN) antibiotic, and Dulbecco's modified Eagle's medium (DMEM) were procured from Gibco BRL (Grand Island, NY, USA). 3-(4,5-Dimethylthiazol-2-yl)-2,5diphenyltetrazolium bromide (45989, MTT-CAS 298-93-1-Calbiochem), dimethyl sulfoxide (DMSO), annexin-V/FITC/PI detection kits were obtained from Calbiochem, CA, USA. Plastic wares were procured from Genetix Biotech Asia Pvt. Ltd. HCT 116, Hep G2, A549, HEK 293 cell line was obtained from National Centre for Cell Science (NCCS), Pune, India.

\subsection{Plant procurement and identification}

\subsubsection{Andrographis nallamalayana J.L.Ellis}

2.2.1.1 Description. Procumbent herb with woody rootstock, 25-50 cm high; glabrous, very sparsely puberulous when young, black when dry. Leaves obovate or elliptic, glabrous. Flowers pedicellate, axillary and terminal racemes; pedicel $1.5 \mathrm{~cm}$ long. Capsule elliptic-oblong, sharply pointed, sparsely hairy. Seeds 4-6, brown, rugose.

2.2.1.2 Specimen examined. Jyothi forest, Kadapa (YSR), Andhra Pradesh, India, $5110 \mathrm{CN} \&$ AMR, 02-09-2018. Coordinates: $15^{\circ} 0240.04^{\prime} \mathrm{N}, 78^{\circ} 4841.46^{\prime} \mathrm{E}, 356 \mathrm{~m}$.

\subsubsection{Andrographis paniculata (Burm. f.) Nees}

2.2.2.1 Description. Perennial, erect or procumbent branched herb, 30 to $90 \mathrm{~cm}$ height; branches quadrangular, slightly winged. Leaves linear-obovate glabrous, apex acuminate. Panicle branches zigzag to $15 \mathrm{~cm}$ terminal; flowers unilateral, distant. Capsule oblong compressed minutely hairy; seeds $8-12$, rugose.

2.2.2.2 Specimen examined. Mallelathertham waterfalls, Mannur (NKL), Telangana, India, 5141 CN \& AMR, 28-10-2018. Coordinates: $16^{\circ} 15^{\prime} 961^{\prime \prime} \mathrm{N} 78^{\circ} 51^{\prime} 335^{\prime \prime} \mathrm{E}, 596 \mathrm{~m}$.

The plants were adequately identified by taxonomist Dr A. Madhusudhana Reddy, Associate Professor, Dept. of Botany, 
Yogi Vemana University, Kadapa, Andhra Pradesh, India, in consultation with Herbarium of Botanical Survey of India (BSI) Deccan Regional Centre, Hyderabad. The above voucher numbers given to the herbarium sheets, and the herbarium sheets were deposited in the Herbarium, Department of Botany, Yogi Vemana University, Kadapa, Andhra Pradesh, India (ESI Fig. 1†).

\subsection{Extraction and isolation}

The leaves of A. nallamalayana (400 g) and A. paniculata (800 g) were shade dried for 7-8 days to achieve an optimum moisture content varied from $7 \%$ and $9 \%$, respectively, before grinding to lesser particle size. The powdered leaves were defatted with petroleum ether $(3 \times 48 \mathrm{~h})$ and then extracted with methanol ( 3 $\times 72 \mathrm{~h}$ ) at room temperature using the cold maceration method. The methanol extracts of $A$. nallamalayana $(53.38 \mathrm{~g})$ and $A$. paniculata $(87.25 \mathrm{~g})$ were filtered through Whatman filter paper, and the filtrates were concentrated at $40{ }^{\circ} \mathrm{C}$ under reduced pressure. The extracts were stored at $4{ }^{\circ} \mathrm{C}$ in an airtight container until further use.

The crude methanolic extract (47.6 g) of A. nallamalayana was dissolved in a minimum amount of chloroform and adsorbed on silica gel. Air-dried slurry was chromatographed over silica gel (100-200 mesh). The column was eluted with chloroform/methanol in the order of increasing polarity. Eight fractions were collected based on the thin layer chromatography (TLC) profiles, Fraction 1 [FR-1, $100 \% \mathrm{CHCl}_{3}, 7.5 \mathrm{~g}, 15.75 \% \mathrm{w} /$ w], Fraction 2 [FR-2, $\mathrm{CHCl}_{3}: \mathrm{MeOH}(98: 2), 3.2 \mathrm{~g}, 6.72 \% \mathrm{w} / \mathrm{w}$ ], Fraction 3 [FR-3, $\mathrm{CHCl}_{3}: \mathrm{MeOH}$ (95:5), $6.25 \mathrm{~g}, 13.13 \% \mathrm{w} / \mathrm{w}$ ], Fraction 4 [FR-4, $\mathrm{CHCl}_{3}: \mathrm{MeOH}(90: 10), 3.2 \mathrm{~g}, 6.72 \% \mathrm{w} / \mathrm{w}$ ], Fraction 5 [FR-5, $\mathrm{CHCl}_{3}: \mathrm{MeOH}(85: 15), 8.8 \mathrm{~g}, 18.48 \% \mathrm{w} / \mathrm{w}$ ], Fraction 6 [FR-6, $\mathrm{CHCl}_{3}: \mathrm{MeOH}(80: 20), 6.21 \mathrm{~g}, 13.04 \% \mathrm{w} / \mathrm{w}$ ], Fraction 7 [FR-7, $\mathrm{CHCl}_{3}: \mathrm{MeOH}(75: 25), 5.5 \mathrm{~g}, 11.55 \% \mathrm{w} / \mathrm{w}$ ], Fraction 8 [FR-8, $\left.\mathrm{CHCl}_{3}: \mathrm{MeOH}(70: 30), 6.3 \mathrm{~g}, 13.23 \% \mathrm{w} / \mathrm{w}\right]$. Fraction 1 (FR-1, $7.5 \mathrm{~g}$ ) was further chromatographically separated on a silica gel column (100-200 mesh) with chloroform/ methanol in the order of increasing polarity to produce five subfractions (Subfraction 1-1-5) Among these five subfractions; subfraction two [Sub.FR-2, $\mathrm{CHCl}_{3}: \mathrm{MeOH}$ (99:1)] yielded compound 1 (18.9 mg, 0.039\% w/w) and subfraction three [Sub.FR-3, $\left.\mathrm{CHCl}_{3}: \mathrm{MeOH}(98: 2)\right]$ yielded compound 2 (6.9 mg, $0.014 \% \mathrm{w} / \mathrm{w})$. Similarly, further purification of fraction four through silica gel chromatography gave compound 3 $(102.51 \mathrm{mg}, 0.215 \% \mathrm{w} / \mathrm{w})$. The structure elucidation of three compounds was carried out using various spectral techniques such as X-ray crystallography, ${ }^{1} \mathrm{H}$ - and ${ }^{13} \mathrm{C}-\mathrm{NMR}$, mass spectrometry, and comparison with literature.

\subsection{Characterization and structural determination}

Characterization and structural determination of three compounds isolated from methanolic extract of A. nallamalayana were established mainly based on single-crystal X-ray crystallography, 1D NMR and mass spectral studies. The single-crystal X-ray diffraction (XRD) data was collected on a Bruker D8 Venture system (Bruker, Billerica, Massachusetts, United States) with microfocus optics using $\mathrm{CuK} \alpha(\lambda=1.54178)$ radiation. The data for three compounds were analysed and processed using Bruker Apex III software suite ${ }^{34}$ incorporated with multiple tools such as cell_now and RLATT to determine unit cell, SAINT-plus for data reduction SADABS for absorption correction. The structure solution was performed with SHELXT, ${ }^{35}$ and full matrix least-squares refinements were performed using the SHELXL ${ }^{36}$ suite of programs incorporated in either Apex III suite ${ }^{34}$ or Olex 2.0-1.3-alpha. ${ }^{37}$ A Bruker Avance-600 MHz superconducting FT-NMR spectrophotometer (Bruker, Billerica, Massachusetts, United States) with RT-TXI probe used to record ${ }^{1} \mathrm{H}$ and ${ }^{13} \mathrm{C}$ NMR spectra for the isolated compounds in DMSO- $d_{6}$ and tetramethylsilane (TMS) as an internal standard. HRMS of compounds was obtained on Agilent 6545B Q-TOF LC/ MS instrument (Agilent Technologies, Santa Clara, California, United States) in negative ionization mode.

\subsection{Cell culture}

HCT 116 (human colorectal carcinoma), HepG2 (hepatocellular carcinoma), A549 (human lung cancer), HEK 293 (human embryonic kidney cell) cells were grown in a humidified environment below 5\% $\mathrm{CO}_{2}$ in DMEM media combined with $10 \%$ FBS and $1 \%$ antibiotic (PSN) at $37^{\circ} \mathrm{C}$. Cells were harvested with $0.5 \%$ trypsin and seeded at optimum density the day before the experiment was performed.

\subsection{Cytotoxicity assay}

Cytotoxicity of ANM and APM was determined by MTT [(3-(4,5dimethythiazol-2-yl)-2,5-diphenyltetrazolium bromide)] assay. ${ }^{38}$ Cells were seeded into 96 -well plates $\left(1 \times 10^{6}\right.$ per well $)$ and treated with different ANM and APM concentrations for $24 \mathrm{~h}$ before assessment using the MTT assay. Both the extracts were dissolved in $0.05 \%$ of DMSO to achieve extract concentrations of $\left(10,20,40,60,80,100\right.$ and $\left.120 \mu \mathrm{g} \mathrm{ml}^{-1}\right)$ and held in a humidified $\left(5 \% \mathrm{CO}_{2}\right)$ atmosphere and kept in the incubator for $24 \mathrm{~h}$ at $37^{\circ} \mathrm{C}$. MTT ( $5 \mathrm{mg} \mathrm{ml}^{-1}$ ) was added after incubation, and the plates were additionally incubated for another $4 \mathrm{~h}$. Using an ELISA reader, the absorbance of DMSO-soluble intracellular formazan salt was measured at $595 \mathrm{~nm}$. This experiment was carried out in triplicate. The percentage of cell death was determined by calculating the percentage inhibition and $\mathrm{IC}_{50}$ value.

\subsection{Determination of intracellular ROS generation (iROS)}

Reactive oxygen species (ROS) generation was determined using the $2^{\prime}, 7^{\prime}$-dichlorofluorescein diacetate $\left(\mathrm{H}_{2} \mathrm{DCFDA}\right)$ dye which uses an increase in green fluorescence intensity to quantify the intracellular ROS generation with respect to untreated cells. ${ }^{39}$ The cells treated with the ANM $\left(\mathrm{IC}_{50}\right)$ were incubated at $37{ }^{\circ} \mathrm{C}$ with $10 \mu \mathrm{M}$ of $\mathrm{H}_{2} \mathrm{DCFH}$-DA for 30 minutes following the flow cytometer determination (BD LSRFortessa, San Jose, CA, USA). The increase in DCF fluorescence directly redirects the ROS produced inside the cells, representing the mean DCF fluorescence intensity.

\subsection{Detection of apoptosis by flow cytometry}

Cell apoptosis is another critical parameter for the toxicity of materials. The determination of apoptosis and necrosis were 
analysed by flow cytometry using annexin-V-FITC/propidium iodide (PI) detection kit (Calbiochem, CA, USA). ${ }^{40}$ Briefly, in a six-well plate, HCT 116 cells were seeded and treated with ANM $\left(\mathrm{IC}_{50}\right)$ time-dependently up to $48 \mathrm{~h}$ and were stained with annexin-V/FITC-PI as per the direction of the manufacturer (Calbiochem, Merck Millipore, Burlington, Massachusetts, USA). The percentage of live, apoptotic (early and late), and necrotic cells were quantified using a flow cytometer (BD LSR Fortessa, San Jose, CA, USA).

\subsection{Western blotting}

Total protein isolation from HCT 116 cells was performed using cell lysis buffer, which is supplemented by phosphatase and protease inhibitor cocktail; proteins have been quantified by BCA assay kit (Thermo Fisher Scientific). ${ }^{41}$ Using treated and non-treated cells, $40 \mu \mathrm{g}$ of proteins were first isolated and then separated electrophoretically into SDS polyacrylamide gel (12\%) which was later transferred to PVDF membrane (Immobilon-P, Millipore Company, Bedford, MA, USA) by using wet trans-blot system (Transblot: wet transfer cell; Bio-Rad Laboratories, Inc., Hercules, CA, USA). The membranes were blocked with BSA for $2 \mathrm{~h}$ and then incubated with primary antibodies anti-bcl2 (SC7392), anti-cleaved PARP 1 (SC-56196), anti-PUMA- $\alpha$ (SC37701), anti-cleaved-caspase-9 (SC-56076) and anti- $\beta$-actin (SC47778) with $11.707 \pm 2.482 \mu \mathrm{g} \mathrm{ml}{ }^{-1}$, ANM ( $\left.\mathrm{IC}_{50}\right)$ for $0,12,24$, and $48 \mathrm{~h}$. After thorough washing, secondary antibodies were conjugated by the membranes and incubated with HRP. By adding ECL substrates, immunoreactive bands were visualised. $\beta$-Actin was used as loading endogenous control.

\subsection{In vitro wound healing assay}

HCT 116 cells were seeded in 6-well plates and incubated at $37^{\circ} \mathrm{C}$ overnight for $24 \mathrm{~h}$. Using pipette tip thrice washed with PBS, a straight wound was rendered onto the confluence cell layer. The cells in serum-free DMEM medium were then treated with ANM $\left(\mathrm{IC}_{50}\right)$. The wound repopulation gap width was measured and recorded at $0,12,24$ and $48 \mathrm{~h}$ of incubation and was then compared to the original gap size at $0 \mathrm{~h}$. The distance was calculated using the image processing system ImageJ, and the gap size was checked from the digital images at each point in time. ${ }^{42}$

\subsection{Determination of total phenolic and flavonoid content}

The Folin-Ciocalteu (F-C) colorimetric method was used to determine the total phenolic content described earlier. ${ }^{43}$ Different concentrations of gallic acid ( 25 to $1000 \mu \mathrm{g} \mathrm{ml}{ }^{-1}$ ) have been prepared and used to generate the calibration curve using a linear fit $\left(y=0.048 x+0.063, R^{2}=0.987\right)$. Total phenolic content was represented as gallic acid equivalent (GAE) in $\mathrm{mg}$ $\mathrm{g}^{-1}$ of dried extract weight ( $\mathrm{mg}$ of gallic acid per $\mathrm{g}$ dry weight). All the samples were done in triplicates. The aluminium chloride colourimetric method described by Chia-chi Chang et al. was used to determine total flavonoid content. ${ }^{44}$ Various quercetin concentrations ranging from 0 to $500 \mu \mathrm{g} \mathrm{ml}^{-1}$ have been prepared and used to generate the calibration curve. The total content of flavonoid was calculated by using the calibration curve $\left(y=0.063 x+0.131, R^{2}=0.970\right)$ and expressed in quercetin equivalents $(\mathrm{QE})$ per gram dry extract weight. All the other determinations were carried out in triplicate.

\subsection{UPLC-QTOF-MS and MS/MS analysis}

Metabolite separation of $A$. nallamalayana and A. paniculata methanolic extract was performed on the Agilent 1290 Infinity LC system. $1.0 \mathrm{mg}$ of dried extract was dissolved in $1 \mathrm{ml}$ of LCMS-grade methanol containing $0.1 \%$ formic acid (v/v) and filtered through a $0.2 \mu \mathrm{m}$ PTFE membrane filter before the analysis was performed. The chromatographic separation was achieved on Agilent ZORBAX SB-C18 column $(2.1 \times 100 \mathrm{~mm}, 1.8$ $\mu \mathrm{m})$ as the stationary phase. A linear gradient of $0.1 \%(\mathrm{v} / \mathrm{v})$ aqueous formic acid (A) and acetonitrile (B): 0-20.0 min, 10-40\% B (v/v); 20.0-22.0 $\mathrm{min}, 40-100 \%$ В (v/v); $22.0-26.0 \mathrm{~min}, 100 \% \mathrm{~B}(\mathrm{v} / \mathrm{v})$; 26.0-27.0 min, 100-10\% B (v/v); 27.0-30.0 min, 10\% B was used as mobile phase. Before the next injection, the column was reconditioned for 5 minutes. $0.5 \mathrm{ml} \mathrm{min}^{-1}$ flow rate with a $0.5 \mu \mathrm{l}$ injected volume was used for analysis, the UPLC system assembled with a diode array detector (DAD) and an autosampler.

The Agilent 1290 Infinity LC device was coupled to Agilent 6545B Accurate-Mass Quadrupole Time-of-Flight (QTOF) for MS/MS study with Agilent Jet Stream Thermal Gradient Technology with electrospray ionisation (ESI) source. The analysis was performed in both positive and negative ionisation mode to obtain high-resolution mass spectra. The ESI parameters have been optimised as: the flow of drying gas $\left(\mathrm{N}_{2}\right), 81 \mathrm{~min}^{-1}$; temperature of drying gas, $150{ }^{\circ} \mathrm{C}$. Other parameters were set as: fragmentor voltage, $150 \mathrm{~V}$; skimmer voltage, $65 \mathrm{~V}$; capillary voltage, $3500 \mathrm{~V}$; nebuliser gas, 35 psig; nozzle voltage $1500 \mathrm{~V}$. Fixed collision energies of 10, 20, 30, 40, 50 and $70 \mathrm{~V}$ were used for MS/MS analysis. The UPLC-QTOF data acquisition was performed using Agilent MassHunter Acquisition B.06.01 software (Agilent Technologies, Santa Clara, CA, USA). With Agilent MassHunter Qualitative Analysis B.07.00 (MassHunterQual, Agilent Technologies), the data were deconvoluted into individual chemical peaks using Molecular Feature Extractor (MFE). The prediction of molecular formula and accurate molecular mass for putative molecules were screened in databases such as METLIN, CAS and MassBank. Agilent Technologies has provided an accurate mass MS/MS Library (PCDL) for the METLIN Personal Compound Database. METLIN PCDL contains all compounds and additionally accurate mass QTOF-MS/MS library reference spectra.

\subsection{HPLC-UV analysis of characterised compounds in crude methanolic extracts of $A$. nallamalayana}

$10 \mathrm{mg}$ of vacuum-dried methanolic extract was dissolved in $1 \mathrm{ml}$ of HPLC-grade methanol and filtered through a $0.2 \mu \mathrm{m}$ PTFE membrane filter before analysis. Authentic commercial standards of chlorogenic acid, 3,4-di-O-caffeoylquinic acid, hispidulin 7-glucoside, oroxylin $\mathrm{A}$ and isolated compounds, i.e. compound $\mathbf{1}, \mathbf{2}$ and 3 , were accurately weighed and dissolved in HPLC-grade methanol to achieve a concentration of $1 \mathrm{mg} \mathrm{ml}^{-1}$. The analysis was carried out in an HPLC system (Shimadzu, Kyoto, Japan) equipped with LC-20AD and LC-20AT prominence liquid chromatography pump, DGU- $20 \mathrm{~A}_{3}$ prominence degasser, CBM-20A prominence communications bus module, SPD-20A 
prominence UV/VIS detector. An aliquot of $20 \mu \mathrm{l}$ was injected using SIL-20AC HT prominence autosampler. The separation was achieved on a Phenomenex reverse phase HPLC column (Luna ${ }^{\circledR} \mathrm{RP} \mathrm{C}_{18}$ column $4.6 \times 260 \mathrm{~mm}, 5 \mu$ particle size, column temperature; $25{ }^{\circ} \mathrm{C}$ ), and elution was carried out using mobile phase consisted of water (A) and acetonitrile (B) with a gradient system, i.e., 0-40 $\mathrm{min}, 0-70 \% \mathrm{~B} ; 40-50 \mathrm{~min}, 70-100 \% \mathrm{~B}$; $50-$ $60 \mathrm{~min}, 100 \% \mathrm{~B}$; 60-65 $\mathrm{min}, 0 \% \mathrm{~B}$, flow $1 \mathrm{ml} \mathrm{min}^{-1}$. The eluate was monitored at $254 \mathrm{~nm}$ and $320 \mathrm{~nm}$. Data analysis was performed by LC solution version 1.25 (Shimadzu, Kyoto, Japan).

\subsection{Prediction of the in silico biological activity}

2.14.1 In silico prediction of anticancer activity using PASS. PASS (prediction of activity spectra for substances), a software program, was used to obtain the identified compounds biological activity spectrum, including the anticancer activity. PASS is a widely used web tool (http:/www.pharmaexpert.ru/ passonline) that contains more than 1 million biologically relevant compounds and can predict 7000 different pharmacological effects with 95\% accuracy according to leave-one-out cross-validation (LOOCV) estimation. The program is based on the multilevel neighbourhoods of atoms (MNA). MNA descriptors were used to represent the chemical structure, and the prediction of activity is usually based on the structureactivity relationship (SAR) analysis of the training set according to the Bayesian algorithm. ${ }^{45-47}$ PASS represents the activity spectrum as "probable activity (Pa) or probable inactivity (Pi)". The experimental value of $\mathrm{Pa}$ and $\mathrm{Pi}$ lies within the range of 0.000 to 1.000 . When the value of $\mathrm{Pa}>\mathrm{Pi}$, i.e. if $\mathrm{Pa}>0.7$, then it represents that the compound would be experimentally active. A higher value of $\mathrm{Pa}$ reflects the significant biological effect experimentally and vice versa. ${ }^{\mathbf{4 8 , 4 9}}$ The structure of all the identified phytoconstituents (20 compounds) were obtained from the PubChem database. The structures were submitted using the SMILES format and were subjected to the evaluation of the biological activity spectrum, including the anticancer activity.

2.14.2 In silico prediction of cell line cytotoxicity with CLCPred tool. CLC-Pred (Cell-Line Cytotoxicity Predictor), a freely available web-service for cell-line cytotoxicity profile prediction tool, was used to predict the cytotoxicity of the identified compounds in various cell lines (http://way2drug.com/Cell-line/). This prediction of cytotoxicity is based on the PASS (prediction of activity spectra for substances) program, which uses structure-cell line toxicity relationship using special training sets with leave-oneout cross-validation procedure. The predicted cytotoxicity is represented by $\mathrm{Pa}$ and $\mathrm{Pi}$ values; if $\mathrm{Pa}>0.5$, the probability of cytotoxicity would be high (active), whereas $\mathrm{Pi}$ value represents inactivity. ${ }^{28,50}$ The structures were submitted in SMILES format and subjected for evaluation of cytotoxicity using the CLC-Pred tool.

\subsection{Statistical analysis}

Results were represented as mean \pm SEM of the multiple data points. Statistical importance in the deference was calculated by the analysis of variance (ANOVA) and paired $T$ test using GraphPad Prism (version 8.4.3) software where $p<0.05$ was considered as significant.

\section{Results and discussion}

\subsection{Assessment of in vitro cytotoxicity of crude methanolic extracts of $A$. nallamalayana and A. paniculata}

A comprehensive literature survey indicated only a few reports describe the cytotoxicity of $A$. nallamalayana, ${ }^{\mathbf{2 6}}$ whereas previous studies showed that $A$. paniculata exhibited cytotoxic activities against several tested cancer cell lines. ${ }^{51-54}$ Motivated by these findings, we were also interested in investigating the role of ANM as an anti-proliferative agent. Our study revealed that methanolic extract of $A$. nallamalayana (ANM) and A. paniculata (APM) showed significant cytotoxicity towards three different types of cancer cell lines HepG2 (hepatocellular carcinoma), A549 (human lung cancer), HCT 116 (human colorectal carcinoma) in a dose-dependent manner as shown in Fig. 1A-C. Compared to APM, ANM effectively reduced cell viability in all tested cancer cell lines. The cytotoxicity of ANM was nearly four times higher than APM in HCT 116 and HepG 2 cells. In HCT 116 cells, the $\mathrm{IC}_{50}$ of ANM and APM was $11.71 \pm 2.48 \mu \mathrm{g} \mathrm{ml}^{-1}$ and $45.32 \pm 0.86 \mu \mathrm{g} \mathrm{ml}^{-1}$, respectively, whereas, in HepG2 cells, it was $15.65 \pm 2.25 \mu \mathrm{g} \mathrm{ml}^{-1}$ and $60.32 \pm 1.05 \mu \mathrm{g} \mathrm{ml}^{-1}$, respectively. Cytotoxicity of these two extracts was comparatively similar in A549 cells (Table 1). Both extracts did not show significant cytotoxicity in HEK 293 cell line (human embryonic kidney cell) up to $120 \mu \mathrm{g}$ $\mathrm{ml}^{-1}$ concentration (Fig. 1D). Andrographolide was used as the positive control, and the $\mathrm{IC}_{50}$ value of andrographolide $\left(42.723 \pm 0.668 \mu \mathrm{g} \mathrm{ml} \mathrm{m}^{-1}\right)$ in HCT 116 cells was similar to the methanolic extract of $A$. paniculata (Fig. 1E). Our results are consistent with the prior studies, where an alcoholic extract of $A$. paniculata exhibited cytotoxic activity against HT-29 (human colon) and IMR-32 (human neuroblastoma) cancer cell lines resulted in $51.25 \pm 0.85$ and $50.25 \pm 1.6 \%$ inhibition at $200 \mu \mathrm{g} \mathrm{ml}{ }^{-1}$, respectively. ${ }^{51}$ In another study, methanolic extract of $A$. paniculata demonstrated significant anti-proliferative activity in MCF-7 (breast cancer) cell lines with minimum inhibition at a concentration of 31.25 $\mu \mathrm{g} \mathrm{ml}{ }^{-1} \cdot{ }^{52}$ Dichloromethane fraction of methanol extract is also reported to maintain active compounds that contribute to the anticancer and immunostimulatory activity. The dichloromethane fraction significantly reduces the proliferation of HT 29 cells (colon cancer) and increases the proliferation of human peripheral blood lymphocytes (HPBLs) at low concentrations. ${ }^{53}$ Previously, the methanolic extract of $A$. nallamalayana reported for anti-proliferative activity against A375 and B16F10 melanoma cell lines. ${ }^{26}$ The cytotoxic activity of $A$. nallamalayana and $A$. paniculata was categorise according to the guidelines of National Cancer Institute (NCI) as follows: $\mathrm{IC}_{50} \leq 20 \mu \mathrm{g} \mathrm{ml} \mathrm{m}^{-1}=$ highly active, $\mathrm{IC}_{50} 21-200 \mu \mathrm{g} \mathrm{ml}{ }^{-1}=$ moderately active, $\mathrm{IC}_{50} 201-$ $500 \mu \mathrm{g} \mathrm{ml} \mathrm{m}^{-1}=$ weakly active and $\mathrm{IC}_{50}>501 \mu \mathrm{g} \mathrm{ml}{ }^{-1}=$ inactive..$^{55,56}$ Following the NCI guidelines, it was concluded that both the extracts showed moderate to high activity in cancer cell lines. Further experiments were focused on exploring the mechanism of cytotoxicity of the methanolic extract of A. nallamalayana as it showed the better cytotoxicity as compared to methanolic extract of A. paniculata. 

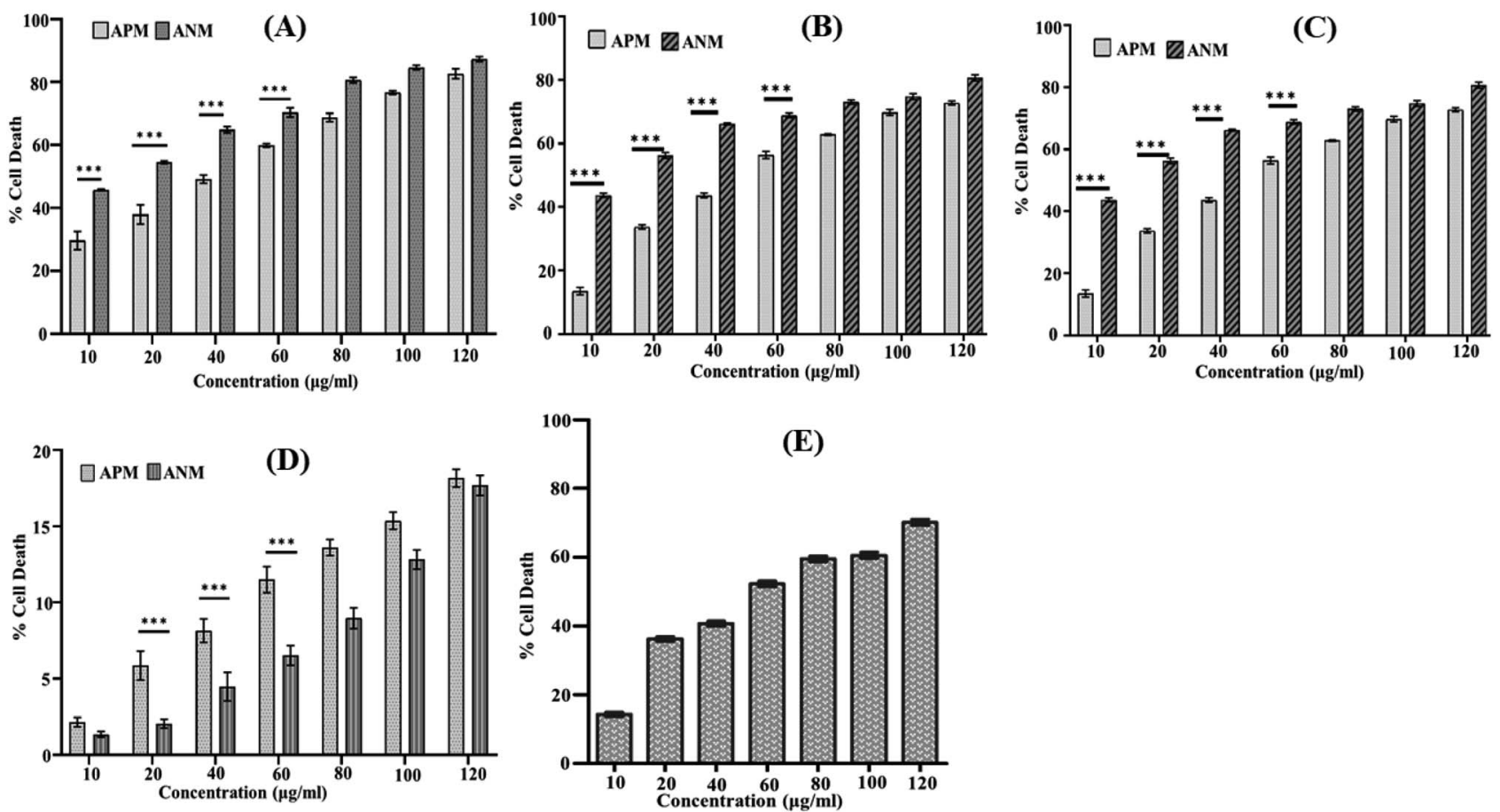

Fig. 1 Cytotoxic effects of ANM and APM on different cancer cell lines: (A) HCT 116; (B) HepG2; (C) A549; (D) HEK 293 cells; (E) cytotoxicity of andrographolide (positive control) in HCT116 cells. All cells $\left(1 \times 10^{6}\right.$ per well) were seeded in a 96 -well plate and treated with different concentrations of ANM and APM extracts $\left(10,20,40,60,80,100\right.$, and $\left.120 \mu \mathrm{g} \mathrm{ml}^{-1}\right)$ for $24 \mathrm{~h}$, and cytotoxicity was determined by MTT assay. Data are expressed as mean \pm SEM for triplicate experiments. Here *** denotes $P$ value $<0.0001$; ** denotes $P$ value $<0.001$.

\subsection{Reactive oxygen species (ROS) generation by crude methanolic extract of $A$. nallamalayana}

It is well established that a rise in intracellular ROS (iROS) levels contribute to apoptosis-induced cell death, causing DNA damage and harm to other cell organelles. ${ }^{57}$ ROS production can be measured by $2^{\prime}, 7^{\prime}$-dichlorodihydrofluorescein diacetate $\left(\mathrm{H}_{2} \mathrm{DCFDA}\right)$, a non-fluorescent molecule. It was observed that following treatment with $11.707 \pm 2.482 \mu \mathrm{g} \mathrm{ml}{ }^{-1}$, ANM $\left(\mathrm{IC}_{50}\right)$, the mean fluorescence intensity of dihydro-dichlorofluorescein (DCF) was increased significantly over time, indicating that ROS generation is directly related to ANM-induced cytotoxicity (Fig. 2). The relative DCF fluorescence intensity in ANM treated HCT16 cells increased in a time-dependent manner.

\subsection{Annexin V-FITC/PI determination by flow cytometry of crude methanolic extract of $A$. nallamalayana}

Activation of apoptosis is an important strategy in the treatment of cancer. The externalisation of phosphatidylserine (PS) from

Table $1 \quad \mathrm{CC}_{50}$ values of ANM and APM crude methanol extract in human cancer cell lines

\begin{tabular}{lll}
\hline Cell line & ANM $\left(\mu \mathrm{g} \mathrm{ml}^{-1}\right)$ & APM $\left(\mu \mathrm{g} \mathrm{ml}^{-1}\right)$ \\
\hline HCT 116 & $11.717 \pm 2.482$ & $45.325 \pm 0.859$ \\
HepG2 & $15.651 \pm 2.258$ & $60.325 \pm 1.054$ \\
A549 & $81.868 \pm 1.236$ & $97.467 \pm 1.496$ \\
HEK 293 & $>120$ & $>120$ \\
Andrographolide & $42.723 \pm 0.668$ & -
\end{tabular}

the inner membrane to the cell's outer membrane is the main characteristic of early apoptosis, and late apoptosis is achieved through DNA fragmentation. ${ }^{58}$ To examine the possible induction of cell death (necrosis and/or apoptosis), experiment was performed using annexin V/propidium iodide assay by studying the exposed level of phosphatidylserine in the outer membrane of cells. ${ }^{59}$ In this assay, Q3, Q4, Q2 and Q1 reflect living cells, early apoptotic (EA), late apoptotic (LA), and necrotic, respectively. The percentage of apoptotic (early and late) cells were significantly increased in a time-dependent manner $(5.3 \% \mathrm{EA} / 28.1 \%$ LA for $12 \mathrm{~h}, 5.9 \% \mathrm{EA} / 30.2 \% \mathrm{LA}$ for $24 \mathrm{~h}$ and $8.3 \% \mathrm{EA} / 54.1 \%$ LA for $48 \mathrm{~h}$ ) compared to control cells (0.7\% EA and $3.1 \% \mathrm{LA})$ in ANM $\left(\mathrm{IC}_{50}\right)$ treated cells (Fig. 3). A significant number of annexin-V-FITC positive cells indicated that ANM induced cytotoxicity in HCT 116 cells were triggered through apoptosis. The understanding of apoptosis can be used to develop new targeted medicines that stop cancer cells from growing and spreading.

\subsection{Regulation of apoptosis markers by crude methanolic extract of $A$. nallamalayana}

We investigated the levels of protein expressions related to the induction of apoptosis in HCT 116 cells after treatment with $11.707 \pm 2.482 \mu \mathrm{g} \mathrm{ml}^{-1}$, ANM $\left(\mathrm{IC}_{50}\right)$ for $0,12,24$, and $48 \mathrm{~h}$ to investigate its effect on pro- and anti-apoptotic proteins. Previous studies in colon cancer cells showed that PUMA is a mitochondrial protein, and its mitochondrial position is necessary for apoptosis induction. ${ }^{60}$ PUMA (p53 up-regulated apoptosis modulator) a member of Bcl-2 homology 3 (BH3)- 

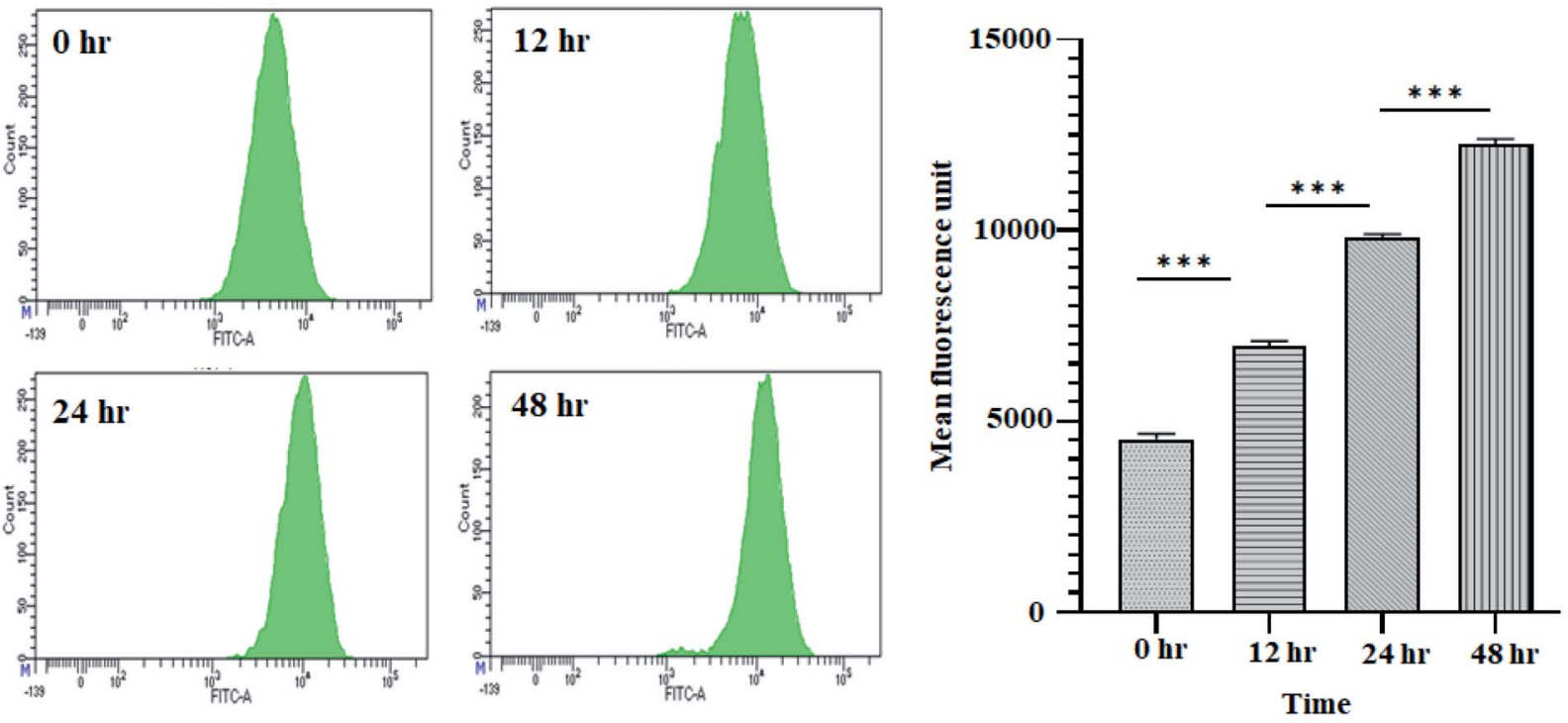

Fig. 2 ANM induces reactive oxygen species (ROS) generation in HCT 116 cells. Cells treated with $11.707 \pm 2.482 \mu \mathrm{g} \mathrm{ml} \mathrm{l}^{-1}, \mathrm{ANM}\left(\mathrm{IC} \mathrm{C}_{50}\right)$, for 0,12 , 24, and $48 \mathrm{~h}$ was studied for DCF fluorescence by flow cytometer. The left panel is for smooth histogram, and the right panel is the bar graph of mean fluorescence intensity. Data are expressed as mean \pm SEM for triplicate experiments. Here $* * *$ denotes $P$ value $<0.0001 ; * *$ denotes $P$ value $<0.001$

only subgroup of Bcl-2 family is one of the most effective killers. PUMA binds to Bcl-2 and Bcl-XL and induces a potential change of the mitochondrial membrane and activation of caspase. ${ }^{61,62}$ Bcl-2 suppresses mitochondrial apoptosis. The caspase family is at the apoptotic machinery centre, where all caspase enzyme plays a significant role in apoptosis execution. Cleavage of PARP-1 (poly[ADP-ribose]polymerase 1) promotes apoptosis by preventing DNA repair-induced survival and by blocking energy depletion-induced necrosis. ${ }^{63}$ PARP-1 cleavage produces an 89
kDa C-terminal fragment (containing the catalytic domain), and the $24 \mathrm{kDa} N$-terminal fragment with the DBD. ${ }^{64}$ It has been shown that the p24 fragment maintains its nucleolar localization, while p89 interacts with intact PARP-1 and blocks the PARP homodimerization, which is essential for enzyme activity. ${ }^{65}$ Western blot analysis showed that the main markers of apoptosis such as cleaved PARP1, PUMA- $\alpha$, and cleavedcaspase 9 and Bcl-2 were up-regulated and down-regulated in ANM treated HCT cells (Fig. 4).

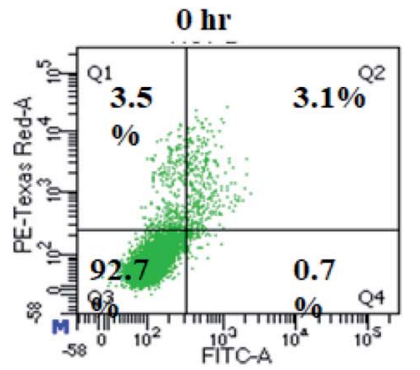

$24 \mathrm{hr}$

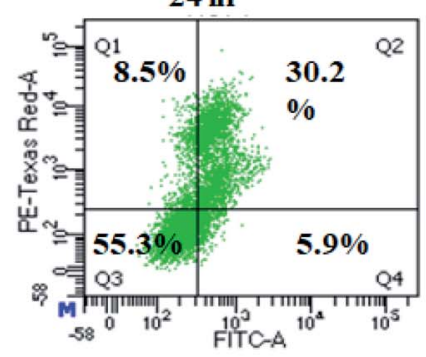

$12 \mathrm{hr}$

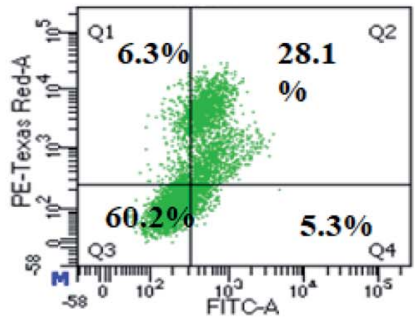

$48 \mathrm{hr}$

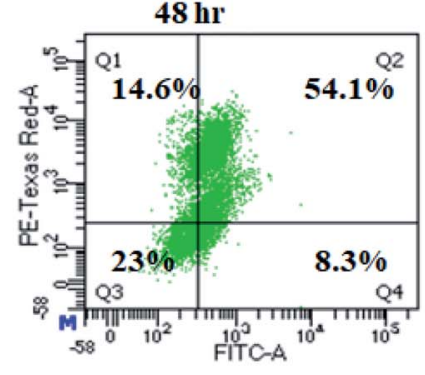

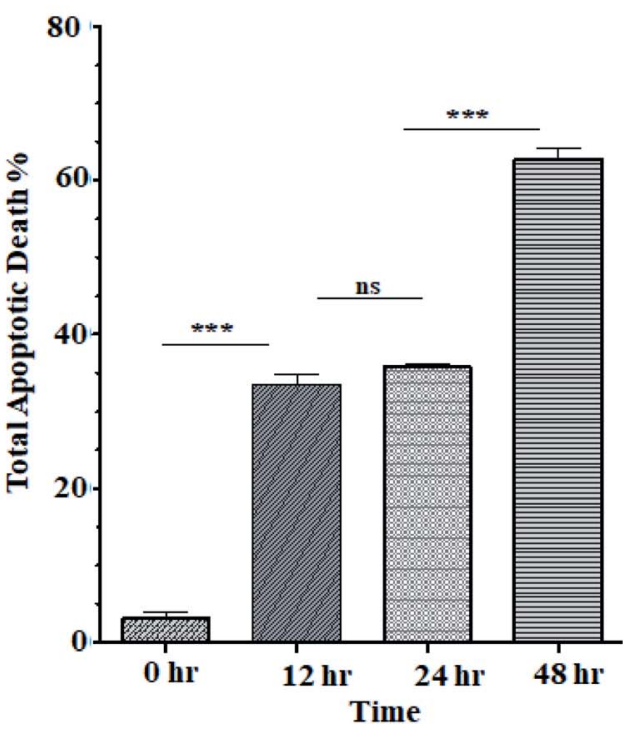

Fig. 3 Flow cytometry analysis of annexin V-FITC/PI: HCT 116 cells were treated without or with ANM IC 50 concentration value of $11.707 \pm$ $2.482 \mu \mathrm{g} \mathrm{ml}^{-1}$ and incubated for $0,12,24,48 \mathrm{~h}$ and analyzed by flow cytometer. The left column presents by the scattered plot of viable cells $(Q 3)$, percent dead cells at early apoptotic (Q4), late apoptotic (Q2), and necrotic phases (Q1). The right column presents a bar diagram of total apoptotic cells at different time points. Data are expressed as mean \pm SEM for triplicate experiments. Here $* * *$ denotes $P$ value $<0.0001 ; * *$ denotes $P$ value $<0.001$, and ns indicates non-significant. 

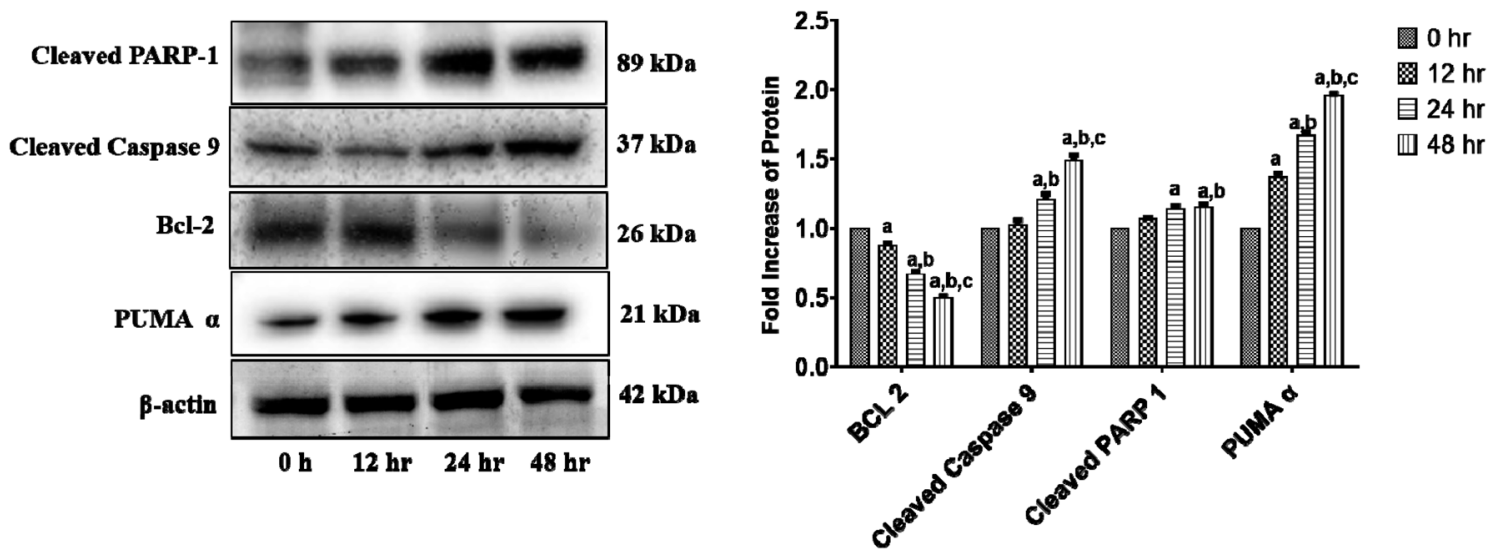

Fig. 4 ANM alters the expression of intrinsic apoptosis pathway-related proteins in HCT 116 cells. Cells were treated with $11.707 \pm 2.482 \mu \mathrm{g} \mathrm{ml} \mathrm{l}^{-1}$, ANM $\left(I C_{50}\right)$ for $0,12,24,48$ h. Expression levels of PUMA- $\alpha$, Bcl-2, cleaved-caspase 9, and cleaved PARP-1 were detected by western blotting, and $\beta$-actin was used as the loading control. The blots were developed and captured by Azure Bio-system. The right column presents a bar diagram of densitometry data at different time points. Data are expressed as mean \pm SEM for triplicate experiments. Here (a) $p<0.05$ compared to $0 \mathrm{~h}$, (b) $p<0.05$ compared to $12 \mathrm{~h}$, (c) $p<0.05$ compared to $24 \mathrm{~h}$ [two-way ANOVA followed by Bonferroni post hoc test].

\section{5 vitro wound healing assay of crude methanolic extract of A. nallamalayana}

The study of cell migration is of particular importance in cancer, as metastatic progression is the primary cause of death in cancer patients. Cancer can grow and spread all across the body only if cancer cells can migrate and invade via extracellular matrix (ECM) and intravasate into the bloodstream, binding to a distant site and eventually extravasate to form distant foci. ${ }^{66,67}$ The scratch wound assay was used to assess cell migration, a crucial step in forming metastatic foci. The scratch wound assay was carried out to detect ANM's inhibitory effect on HCT 116 cell migration. After treatment with ANM $\left(\mathrm{IC}_{50}\right)$, the HCT 116 cell migration was decreased in a time-dependent manner $(0,12,24$ and $48 \mathrm{~h}$ ). The result showed fewer or no cells in the denuded region, indicating that ANM could reduce site-specific cell migration (Fig. 5). Decreased migration in HCT 116 cells could be described as decreased metastatic potential. Over cell proliferation and migration are hallmarks of cancerous cells. ${ }^{68}$ The effectiveness of prospective cancer therapies is systematically estimated using in vitro cell-line proliferation screens. However, it is not clear whether tumour aggressiveness is more affected by the proliferative or migratory properties of cancer cells that make the therapy ineffective. ${ }^{69}$ Thus, inhibition of cell proliferation and migration is considered necessary in order to treat cancer effectively. ${ }^{70}$

\subsection{Total phenolic and flavonoid content in crude} methanolic extract of $\boldsymbol{A}$. nallamalayana and $\boldsymbol{A}$. paniculata

Phenolic and flavonoid compounds act as antioxidants due to their redox properties. Total phenolic content could be used as a basis for rapid antioxidant screening because of hydroxyl
$0 \mathrm{hr}$
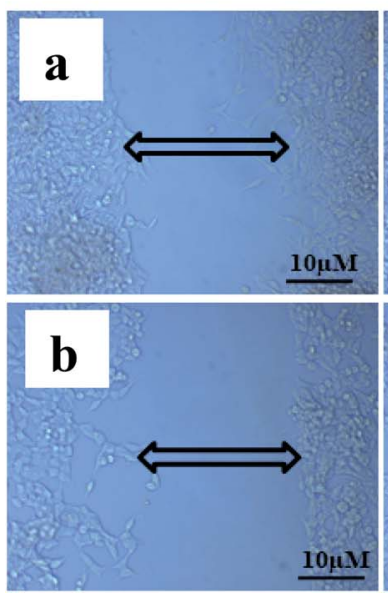

$12 \mathrm{hr}$
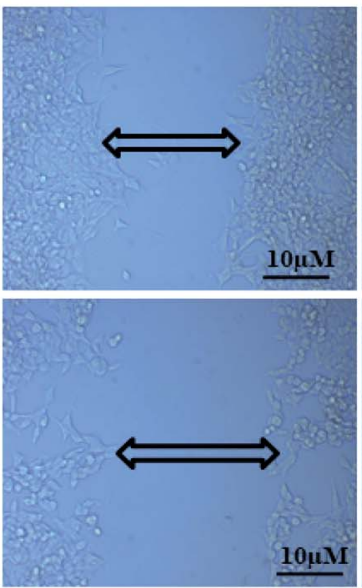

$24 \mathrm{hr}$
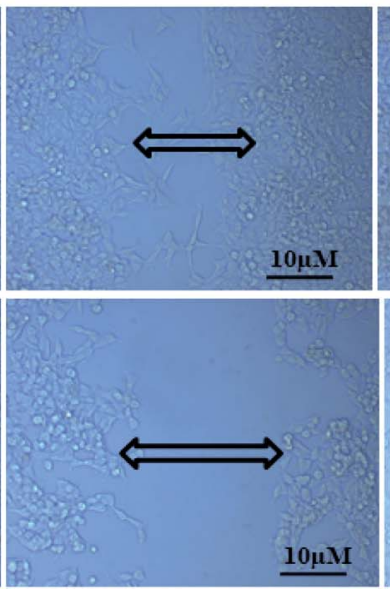

$48 \mathrm{hr}$
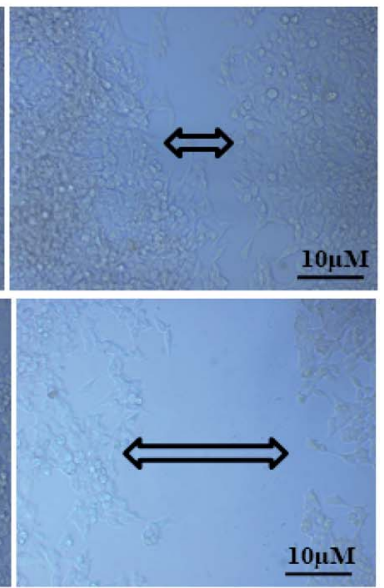

Fig. 5 ANM's inhibitory effect on HCT 116 cell migration. (a) Control cells; (b) $11.707 \pm 2.482 \mu \mathrm{g} \mathrm{ml}^{-1}$, ANM (IC 50$)$ treated cells. After treatment with ANM, the HCT 116 cell migration was decreased in a time-dependent manner $(0,12,24$, and $48 \mathrm{~h})$. The result showed fewer or no cells in the denuded region. 
Table 2 Total phenolic and flavonoids content of methanolic extract of $A$. nallamalayana and $A$. paniculata aerial parts

\begin{tabular}{lll}
\hline Plant & $\begin{array}{l}\text { Total phenolic content } \\
(\mathrm{mg} \text { GAE per } \mathrm{g})\end{array}$ & $\begin{array}{l}\text { Total flavonoid content } \\
(\mathrm{mg} \text { QE per g dry mass }(\mathrm{d} . \mathrm{m} .))\end{array}$ \\
\hline ANM & $357.17 \pm 1.29$ & $474.98 \pm 0.63$ \\
APM & $408.60 \pm 0.58$ & $327.58 \pm 0.90$
\end{tabular}

groups in phenolic compounds that facilitate free radical scavenging. ${ }^{71}$ Total phenolic content was determined using the Folin-Ciocalteu method in each extract. The results were derived from a standard calibration curve $\left(y=0.048 x+0.063, R^{2}\right.$ $=0.987$ ) of gallic acid ( 25 to $1000 \mu \mathrm{g} \mathrm{ml}{ }^{-1}$ ) and expressed in gallic acid equivalents (GAE) per gram dry extract weight. Aluminium chloride colorimetric method was used to measure the flavonoids content in each methanolic extract. The results were derived from the calibration curve $\left(y=0.063 x+0.131, R^{2}=\right.$ $0.970)$ of quercetin $\left(0-500 \mu \mathrm{g} \mathrm{ml}^{-1}\right)$ and expressed in quercetin equivalents $(\mathrm{QE})$ per gram dry extract weight. The results were resumed in Table 2. The total phenolic content was found to be lower in ANM compared to APM while total flavonoid content was higher in ANM than APM. Phenolic and flavonoid are one of the most widely distributed secondary metabolites in the plant kingdom. Their anti-carcinogenic effects are primarily due to their ability to: (a) induce cell cycle arrest; ${ }^{72,73}$ (b) inhibit oncogenic signalling cascades controlling cell proliferation, angiogenesis, and apoptosis; ${ }^{74-77}$ (c) modulate ROS levels; ${ }^{78-80}$ (d) promote tumour suppressor proteins such as $\mathrm{p} 533^{; 1,82}$ and (e) halt cell migration. ${ }^{83,84}$ Multiple studies clearly suggest that the anticancer and apoptosis-inducing properties of polyphenolic compounds is mainly due to their prooxidant action rather than antioxidant activity. ${ }^{85}$ Flavonoids have a dual effect in terms of
ROS homeostasis, acting as antioxidants under normal conditions and as powerful pro-oxidants in cancer cells, activating apoptotic pathways. ${ }^{85,86}$ Because of the presence of phenolic hydroxyl groups, flavonoids may directly scavenge ROS and chelate metal ions. ${ }^{87,88}$ The indirect antioxidant effects of flavonoids are associated with the activation of antioxidant enzymes, the repression of pro-oxidant enzymes, and stimulate the production of antioxidant enzyme and phase II detoxifying enzyme synthesis. ${ }^{88}$ The anticancer activity of flavonoid is mediated by both antioxidant and pro-oxidant activity. ${ }^{89}$ The high flavonoid and phenolic content could be responsible for the cytotoxicity of these crude extracts.

\subsection{Metabolite profiling by UPLC-QTOF-MS (HRMS) analysis of methanolic extract of $A$. nallamalayana and $A$. paniculata aerial parts}

Since the phytochemical analysis showed that the extracts were rich in phenolic and flavonoid contents, they were used to identify and characterise metabolites using UPLC-QTOF-MS analysis. Accurate mass values $(\mathrm{m} / \mathrm{z})$ of all the primary ions identified in UPLC-MS analysis were screened against databases such as Metlin, MassBank and HMDB and literature within five ppm accuracy. Peak identification was carried out by matching retention times (Rt) and mass spectra with literature data and databases. The comparative phytochemical investigation revealed that both species have different chemical constituents. In UPLC-ESI-QTOF-MS analysis, 42 compounds were identified with andrographolides as the major constituents of A. paniculata, whereas a total of 59 compounds were identified from the methanolic extract of A. nallamalayana. Most of the compounds were identified for the first time from this species. Among all the identified compounds from both

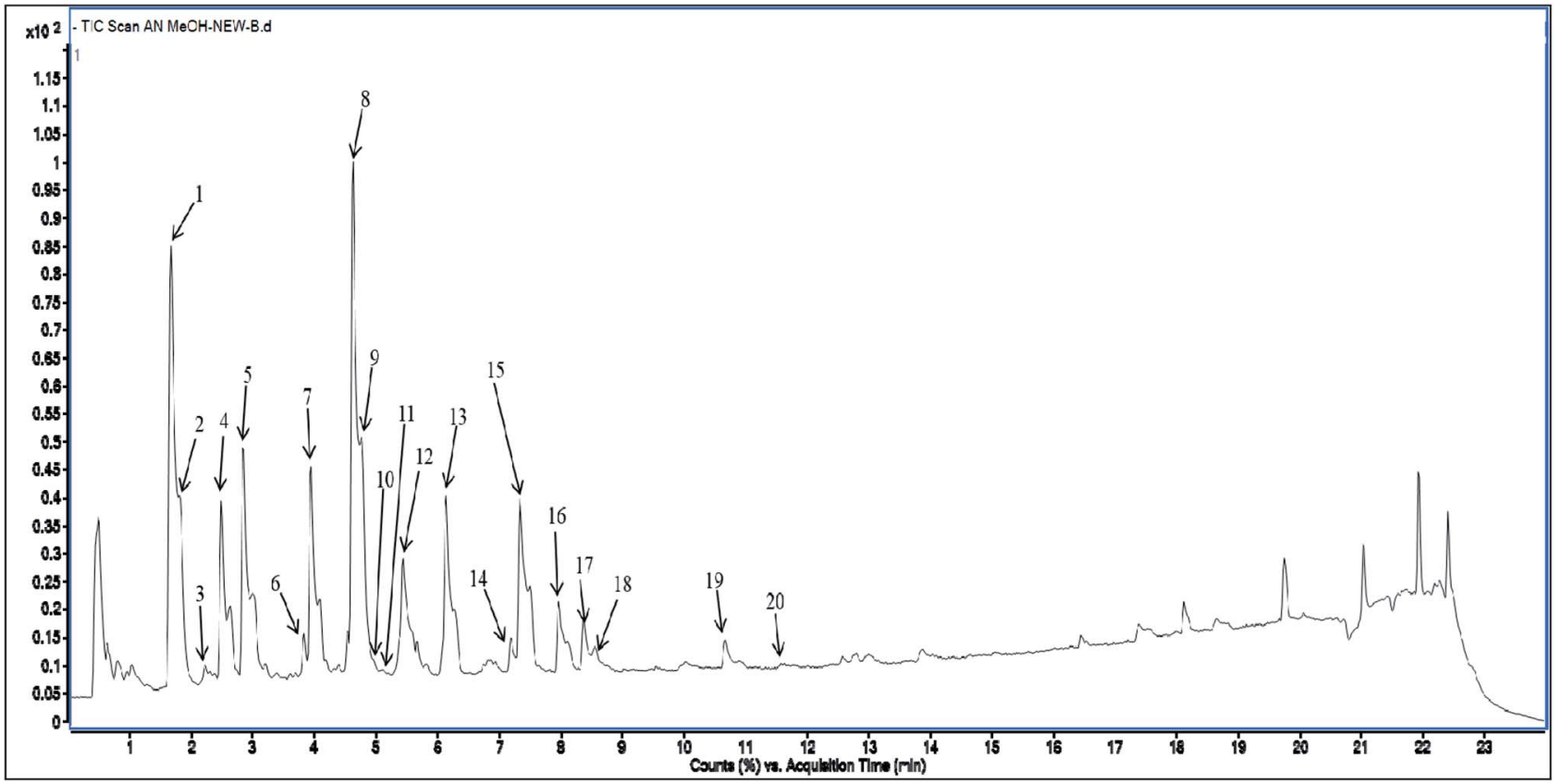

Fig. 6 Total Ion Chromatogram (TIC) of methanol extract of Andrographis nallamalayana in the negative ionization mode. 
species, eight compounds were similar, i.e. chlorogenic acid, andrographidine $\mathrm{B}$, 1,3-dicaffeoylquinic acid, apigenin 7-O- $\beta$ glucuronide, andrographidine $\mathrm{D}$, andropaniculoside $\mathrm{A}$, skullcapflavone I, oroxylin A (ESI Fig. $2 \dagger$ ). The phytochemicals characterisation revealed that the identified compounds belong to phenolic acids, diterpenoids, flavonoids, and their glycosides. The names of the identified compounds, molecular formula, experimental mass $(\mathrm{m} / \mathrm{z})$, peak height, the retention time (min), score and adduct/ion species are summarised in ESI Tables S1 and S2.†

\subsection{UPLC-QTOF-MS/MS analysis of methanolic extract of $\boldsymbol{A}$. nallamalayana aerial parts}

Methanolic extract of $A$. nallamalayana aerial parts was analysed by UPLC-QTOF-MS/MS analysis using positive and negative ionisation mode. Usually, flavonoids in the negative mode exhibit better sensitivity and a cleaner mass spectral background than the positive mode. In the case of positive mode when there is no collision energy applied, most flavonoids usually gave $[\mathrm{M}+\mathrm{H}]^{+},[\mathrm{M}+\mathrm{Na}]^{+}$as molecular adduct ions along with different fragment ions in the complete scan mode, whereas most flavonoids predominantly yielded $[\mathrm{M}-\mathrm{H}]^{-}$ions in the negative mode. ${ }^{90}$ Therefore, the negative ion mode detection was selected for the analysis. A bunch of peaks were eluted with high relative abundance in the range of 1.5-15 minutes. All the compounds were characterised by their retention time, accurate mass, fragmentation patterns and UV spectra and by comparing it with the literature data. The total ion chromatograms (TIC) of the ANM and APM in the LC-MS/MS analysis are shown in Fig. 6 and 7. According to their elution order, compounds were numbered, keeping the same numbering of peaks. Four caffeoylquinic acids, one anthocyanidin-3-O-glycoside and 15 flavones/flavanol and their glycosides were characterised. For each identified compound, the UPLC-QTOF-MS/MS data were resumed in Table 3.

3.8.1 Identification of phenolic acids. In the methanolic extract of A. nallamalayana, four caffeoylquinic acids were identified, but their correct identification is a rather tricky job due to widespread isomerism (geometrical and regional). In quinic acid, the linkage position of caffeoyl groups for monoacyl caffeoylquinic acids could be identified based on their characteristic fragmentation pathways. Diagnostic fragmentation ions (DFIs), e.g. $\mathrm{m} / \mathrm{z} 173,179$ and 191 corresponds to [quinic acid-H$\mathrm{H}_{2} \mathrm{O}$ ], [caffeic acid-H] ${ }^{-}$and [quinic acid-H] ${ }^{-}$respectively, were suggested or calculated from the analysis of fragmentation pattern for each chemical class of chlorogenic acids (CGAs). ${ }^{91}$

Compound 1 (peak 1) displayed a deprotonated molecular ion peak at $m / z 353.09[\mathrm{M}-\mathrm{H}]^{-}$. In mass fragmentation, the base peak at $m / z 191.0556$ was obtained from the moiety of the quinic acid, [quinic acid-H] ${ }^{-}$. Additionally, the secondary peak at $\mathrm{m} / \mathrm{z}$ 179.0344 $\left(\mathrm{C}_{9} \mathrm{H}_{7} \mathrm{O}_{4}\right)$ was derived from the moiety of caffeic acid, $[\text { caffeic acid-H }]^{-}$, together with a daughter ion at $m / z 161.025$. Compound 1, based on the fragmentation patterns and pseudo molecular ion at $\mathrm{m} / \mathrm{z} 353$ in the MS/MS experiment, was tentatively characterised and identified as chlorogenic acid. ${ }^{\mathbf{9 2}}$ No distinct difference was observed in the MS/MS spectra of compound 1 and compound 2, but a secondary peak at $\mathrm{m} / \mathrm{z}$ 135.0448 $\left(\mathrm{C}_{8} \mathrm{H}_{7} \mathrm{O}_{2}\right)$, [caffeic acid- $\left.\mathrm{H}-\mathrm{CO}_{2}\right]^{-}$displayed by compound $\mathbf{1}$, which was absent in the spectra of compound 2. Based on the fragmentation pattern and previous literature reports, compound 2 (peak 2) was tentatively identified as 1-Ocaffeoylquinic acid. ${ }^{93}$ Compounds 4 (peak 4) showed the $[\mathrm{M}-\mathrm{H}]^{-}$ at $m / z 515\left(\mathrm{C}_{25} \mathrm{H}_{24} \mathrm{O}_{12}\right)$. The data analysed by mass suggested that this compound might be di-caffeoylquinic acids (DCQAs). The deprotonated molecular ions in the mass fragmentation spectra yielded characteristic fragments at $\mathrm{m} / \mathrm{z} 353$ [caffeoylquinic acid-H] $]^{-}, 191$ [quinic acid-H] $]^{-}, 179$ [caffeoyl-H] $]^{-}, 173$ [quinic acid- $\left.\mathrm{H}-\mathrm{H}_{2} \mathrm{O}\right]^{-}$and 135 [caffeoyl-H-COO] ${ }^{-}$, which are specific to caffeoylquinic acids. The three isomeric compounds could be distinguished based on the relative intensity of molecular ion at $m / z 335\left[\mathrm{CQA}-\mathrm{H}_{2} \mathrm{O}-\mathrm{H}\right]^{-}$. The base peak intensity at $\mathrm{m} / \mathrm{z} 335$ was higher in 3,4-DCQA (26\% of base peak), barely detectable in 4,5-DCQA ( $2 \%$ of base peak). Fragment ion at $\mathrm{m} / \mathrm{z} 173$ in 3,4-DCQA mass spectrum was indicative of

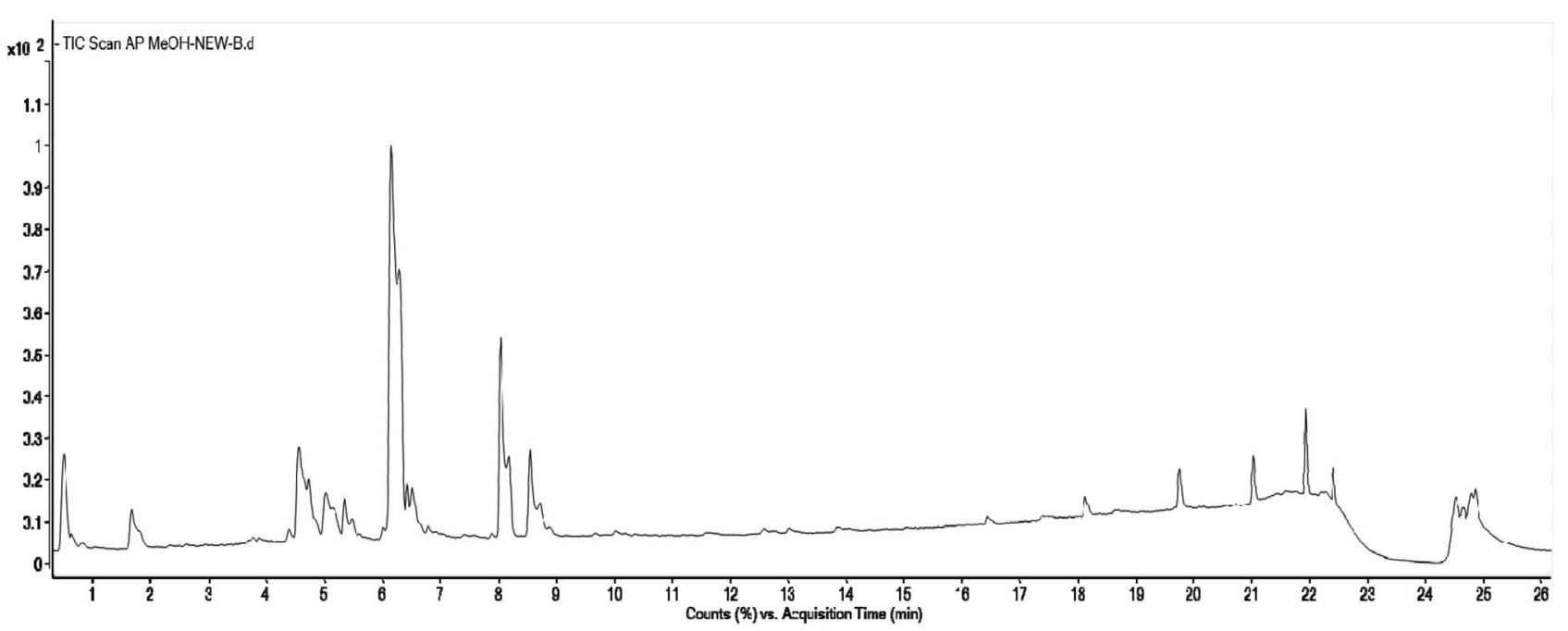

Fig. 7 Total Ion Chromatogram (TIC) of methanol extract of Andrographis paniculata in the negative ionization mode. 
Table 3 Compounds identified by UPLC-QTOF-MS/MS analysis in methanol extracts of $A$. nallamalayana

\begin{tabular}{|c|c|c|c|c|c|c|c|c|c|}
\hline $\begin{array}{l}\text { Peak } \\
\text { no. }\end{array}$ & $\begin{array}{l}\mathrm{RT} \\
(\mathrm{min})\end{array}$ & $\begin{array}{l}\text { HPLC-DAD } \lambda_{\max } \\
(\mathrm{nm})\end{array}$ & $\begin{array}{l}{[\mathbf{M}-\mathbf{H}]^{-}} \\
(m / z)\end{array}$ & $\begin{array}{l}\text { Delta } \\
\text { ppm }\end{array}$ & $\begin{array}{l}\text { Fragments ions } \\
(\mathrm{m} / \mathrm{z})\end{array}$ & $\begin{array}{l}\text { Accurate } \\
\text { mass }\end{array}$ & $\begin{array}{l}\text { Proposed } \\
\text { molecular } \\
\text { formula }\end{array}$ & Identification & References \\
\hline 1 & 1.66 & 217,240 sh, 324 & 353.090 & -7.6 & $191,179,135,173$ & 354.095 & $\mathrm{C}_{16} \mathrm{H}_{18} \mathrm{O}_{9}$ & Chlorogenic acid & 92 \\
\hline 2 & 1.81 & 233,305 sh, 328 & 353.090 & -7.6 & $191,179,173,161$ & 354.095 & $\mathrm{C}_{16} \mathrm{H}_{18} \mathrm{O}_{9}$ & 1-O-Caffeoylquinic acid & 93 \\
\hline 3 & 2.21 & $255,267 \mathrm{sh}, 352$ & 477.105 & -4.1 & 314,299 & 478.111 & $\mathrm{C}_{22} \mathrm{H}_{22} \mathrm{O}_{12}$ & Isorhamnetin 3-glucoside & 103 \\
\hline 4 & 2.48 & $243,303 \mathrm{sh}, 325$ & 515.122 & -5.2 & $353,179,191,135$ & 516.127 & $\mathrm{C}_{25} \mathrm{H}_{24} \mathrm{O}_{12}$ & 3,4-Di-O-caffeoylquinic acid & 92 and 94 \\
\hline 5 & 2.83 & 226,334 & 461.111 & -5.3 & $299,341,285$ & 462.116 & $\mathrm{C}_{22} \mathrm{H}_{22} \mathrm{O}_{11}$ & $\begin{array}{l}\text { Hispidulin 7-glucoside } \\
\text { (homoplantaginin) }\end{array}$ & 104 \\
\hline 6 & 3.82 & $256,266 \mathrm{sh}, 348$ & 447.095 & -5.2 & $285,175,151,133$ & 448.101 & $\mathrm{C}_{21} \mathrm{H}_{20} \mathrm{O}_{11}$ & Luteolin $4^{\prime}$-glucoside & 105 \\
\hline 7 & 3.94 & $256,271,349$ & 567.118 & -4.6 & $285,151,101$ & 568.122 & $\mathrm{C}_{28} \mathrm{H}_{24} \mathrm{O}_{13}$ & Neobignonoside & 106 and 107 \\
\hline 8 & 4.62 & 275,327 & 461.112 & -5.8 & $323,299,165,284,118$ & 462.443 & $\mathrm{C}_{22} \mathrm{H}_{22} \mathrm{O}_{11}$ & $\begin{array}{l}5,2^{\prime}, 6^{\prime} \text {-Trihydroxy-7- } \\
\text { methoxyflavone } \\
2^{\prime}-O-\beta \text {-D-glucopyranoside }\end{array}$ & 108 \\
\hline 9 & 4.77 & 240,260 sh, 344 & 461.112 & -6.6 & $341,299,165,133,137$ & 462.116 & $\mathrm{C}_{22} \mathrm{H}_{22} \mathrm{O}_{11}$ & $\begin{array}{l}\text { Luteolin 7-methyl ether } \\
5 \text { - } \beta \text {-D-glucoside }\end{array}$ & 109 \\
\hline 10 & 4.94 & $229,287,309$ & 337.095 & -6.6 & $191,173,163,119$ & 338.100 & $\mathrm{C}_{16} \mathrm{H}_{18} \mathrm{O}_{8}$ & 3-p-Coumaroyl quinic acid & 95 \\
\hline 11 & 5.07 & 277,333 & 461.112 & -6.4 & $299,165,161,341$ & 462.166 & $\mathrm{C}_{22} \mathrm{H}_{22} \mathrm{O}_{11}$ & $\begin{array}{l}\text { Scutellarein 7-methyl ether } \\
\text { 6-galactoside }\end{array}$ & 110 \\
\hline 12 & 5.43 & $258,294,332$ & 581.133 & -3.8 & $299,165,133$ & 582.137 & $\mathrm{C}_{29} \mathrm{H}_{26} \mathrm{O}_{13}$ & $2^{\prime \prime}-O$-Vanilloylvitexin & 96 \\
\hline 13 & 6.13 & 272,307 & 429.085 & -5.8 & $253,175,113$ & 430.090 & $\mathrm{C}_{21} \mathrm{H}_{18} \mathrm{O}_{10}$ & Chrysin 7-glucuronide & 111 \\
\hline 14 & 7.18 & 279,320 & 461.112 & -3.6 & 299 & 461.110 & $\mathrm{C}_{22} \mathrm{H}_{22} \mathrm{O}_{11}$ & Peonidin 3-O-galactoside & 112 \\
\hline 15 & 7.33 & 265,335 & 283.063 & -7.4 & $268,240,165,118$ & 284.068 & $\mathrm{C}_{16} \mathrm{H}_{12} \mathrm{O}_{5}$ & Echioidinin & 97 \\
\hline 16 & 7.96 & 273,321 & 283.063 & -7.1 & $\begin{array}{l}268,240,239,211,196, \\
165\end{array}$ & 284.068 & $\mathrm{C}_{16} \mathrm{H}_{12} \mathrm{O}_{5}$ & Oroxylin A & 98 and 99 \\
\hline 17 & 8.36 & $245,277,316$ & 283.063 & -7.4 & $268,240,211,196,165$ & 284.068 & $\mathrm{C}_{16} \mathrm{H}_{12} \mathrm{O}_{5}$ & Wogonin & 98 and 99 \\
\hline 18 & 8.56 & $250 \mathrm{sh}, 271,372$ & 313.080 & -4.3 & 283,298 & 314.079 & $\mathrm{C}_{17} \mathrm{H}_{14} \mathrm{O}_{6}$ & $\begin{array}{l}\text { 3,5-Dihydroxy-7,8- } \\
\text { dimethoxyflavone }\end{array}$ & 100 \\
\hline 19 & 10.65 & 270,320 & 313.080 & -4.9 & $298,283,255$ & 314.079 & $\mathrm{C}_{17} \mathrm{H}_{14} \mathrm{O}_{6}$ & Skullcapflavone I & 101 \\
\hline 20 & 11.11 & 261,276 sh, 333 & 283.063 & -5.3 & $\begin{array}{l}268,240,239,165,121, \\
117\end{array}$ & 284.068 & $\mathrm{C}_{16} \mathrm{H}_{12} \mathrm{O}_{5}$ & $\begin{array}{l}\text { 7,2'-Dihydroxy-5- } \\
\text { methoxyflavone }\end{array}$ & 102 \\
\hline
\end{tabular}

acylation at 4-position. ${ }^{92,94}$ Finally, compound 4 was provisionally identified as 3,4-di-O-caffeoylquinic acid. Compound $\mathbf{1 0}$ (peak 10) had the molecular ion at $m / z 337[\mathrm{M}-\mathrm{H}]^{-}$and another secondary peak at $m / z 191,173,163,119$ corresponds to [quinic acid- $\mathrm{H}]^{-}$, [quinic acid- $\left.-\mathrm{H}_{-} \mathrm{H}_{2} \mathrm{O}\right]^{-}$, [p-coumaric acid- $\left.\mathrm{H}\right]^{-}$and $[\mathrm{p}-$ coumaric acid- $\left.-\mathrm{H}_{-} \mathrm{CO}_{2}\right]^{-}$respectively. The ion at $\mathrm{m} / \mathrm{z} 173[\mathrm{QA}-$ $\left.\mathrm{H}-\mathrm{H}_{2} \mathrm{O}\right]^{-}$indicated that $4-\mathrm{OH}$ of $\mathrm{QA}$ was substituted. Both compounds mass fragmentation spectra showed that ion at $\mathrm{m} / \mathrm{z}$ $191[\mathrm{QA}-\mathrm{H}]^{-}$was indispensable. According to the fragmentation pattern and literature data compound, $\mathbf{1 0}$ was tentatively identified as 3-p-coumaroylquinic acid. ${ }^{95}$

3.8.2 Identification of flavones. Compound 12 (peak 12) displayed a deprotonated molecular ion peak at $\mathrm{m} / \mathrm{z} 581.1331$ $[\mathrm{M}-\mathrm{H}]^{-}$. The fragmentation pattern suggests that this compound may be a combination of orientin and vitexin derivatives because the retention time and molecular masses were identical. The fragment ions produced were found to be identical to those of the type II flavone C-glycosides. Compounds $\mathbf{1 2}$ were tentatively classified as $2^{\prime \prime}$-O-vanilloylvitexin based on earlier literature studies. ${ }^{96}$ Compound $\mathbf{1 5}$ (peak 15) exhibited deprotonated molecular ion at $m / z 283[\mathrm{M}-\mathrm{H}]^{-}$. The fragment ions at $m / z 165.020$ and 117.035 produced due to the loss of the $\mathrm{C}$ ring of flavone moiety along with a secondary peak at $m / z 267[\mathrm{M}-\mathrm{OH}]^{-}$. Compound 15 generated a radical anion at $m / z 268\left[\mathrm{M}-\mathrm{H}-\mathrm{CH}_{3}\right]^{\circ}$. The loss of a $\mathrm{CH}_{3}^{*}$ radical from the deprotonated ion indicates the occurrence of the methoxy group. Based on the fragmentation behaviour and earlier literature data, compound $\mathbf{1 5}$ was characterised/identified as echioidinin. ${ }^{97}$ Compound $\mathbf{1 6} \& \mathbf{1 7}$ (peak 16 and 17) had the same $\mathrm{m} / \mathrm{z}$ at $283[\mathrm{M}-\mathrm{H}]^{-}$. The electrospray ionisation of compound 16 \& $\mathbf{1 7}$ produced similar fragments ion as compound 16. Six ions were observed in MS/MS spectra for both compounds at $\mathrm{m} / \mathrm{z}$ $268.03\left[\mathrm{M}-\mathrm{H}-\mathrm{CH}_{3}\right]^{-*}, 240.04 \quad[\mathrm{M}-\mathrm{H}-\mathrm{CO}]^{-}, 223.04 \quad[\mathrm{M}-\mathrm{H}-$ $\left.\mathrm{CO}_{2} \mathrm{H}\right]^{-*}, 211.04[\mathrm{M}-\mathrm{H}-\mathrm{CO}]^{-}, 196.05,165.02$ under negative ionisation conditions. Although the fragment ions of compound 16 and 17 were identical, their MS/MS spectra could easily distinguish them. The relative abundance of the fragment ions at $\mathrm{m} / \mathrm{z} 165$ in compound $\mathbf{1 7}$ was higher than the fragment ion at $\mathrm{m} / \mathrm{z} 211$. On the contrary, it was the opposite in the case of compound 16. According to the fragmentation pattern, these isomers were tentatively identified as oroxylin A and wogonin..$^{98,99}$ Compound 18 (peak 18) and compound 19 (peak 19) showed a deprotonated molecular ion at $m / z 313[\mathrm{M}-\mathrm{H}]^{-}$. By analysing their MS/MS spectra, it was concluded that both of them contain two $-\mathrm{OCH}_{3}$ groups since the ions of $\mathrm{m} / \mathrm{z} 298$ and 283 was observed, which indicates the presence of dimethoxylated flavanone. The fragment ion at $m / z 255\left[\mathrm{M}-\mathrm{H}-2 \mathrm{CH}_{3}-\mathrm{CO}\right]^{-}$ indicated a loss of $\mathrm{CO}$ from the parent ion. However, they were significantly different. The intensity of ion at $\mathrm{m} / \mathrm{z} 298$ was very weak in compound 18, whereas compound 19 showed the 
strong intensity of ion at $m / z$ 298. Based on these data and earlier literature reports, compound 18 and 19 were putatively identified as 3,5-dihydroxy-7,8-dimethoxyflavone, ${ }^{\mathbf{1 0 0}}$ and skullcapflavone $\mathbf{I}^{\mathbf{1 0 1}}$ respectively. Compounds $\mathbf{2 0}$ (peak 20) exhibited $[\mathrm{M}-\mathrm{H}]^{-}$ion at $m / z 283$. A stable radical ion was formed at $\mathrm{m} / \mathrm{z}$ 268 correspondings to $\left[\mathrm{M}-\mathrm{H}-\mathrm{CH}_{3}\right]^{-}$. Compound 20 also showed minor daughter ions at $\mathrm{m} / \mathrm{z} 240$ and 239 due to $\mathrm{CH}_{3}{ }^{-}$and $\mathrm{CO}$ or HCO loss, respectively. The peak at $m / z 117$ corresponds to the generation of the B-ring fragments. Fragment ions formed by Aring at $m / z 165$ and $m / z 121$ indicate that methoxyl substituent occurs at the $8^{\text {th }}$ position. Finally, compound 20 was tentatively identified as 7,2'-dihydroxy-5-methoxyflavone. ${ }^{102}$

3.8.3 Identification of flavonoid glycoside. Compound 3 (peak 3) displayed a pseudomolecular ion at $m / z 477.1058$ [M$\mathrm{H}]^{-}$and a secondary fragment ion at $m / z 315[\mathrm{M}-162-\mathrm{H}]^{-}$was formed due to the loss of a hexose moiety. The fragmentation of the pseudo molecular ion also leads to a characteristic fragment ion corresponding to the aglycone moiety at $\mathrm{m} / \mathrm{z} 315$, designated to isorhamnetin. The fragment ion at $m / z 299$ indicates the loss of methyl group from the aglycone part, which confirmed the identification of isorhamnetin 3-O-glucoside based on fragmentation pattern, UV spectra and retention time in the extract of $A$. nallamalayana. ${ }^{103}$ Compound 5 (peak 5) with $m / z$ at 461 [M$\mathrm{H}]^{-}$displayed fragment ion at $\mathrm{m} / z 299$ due to the loss of a hexose moiety and secondary peaks at $m / z$ 341, 285 .
Compound 5 was tentatively identified as hispidulin 7-glucoside (homoplantaginin). ${ }^{\mathbf{1 0 4}}$ Similarly, Compound 6 (peak 6) displayed a deprotonated molecular ion at $m / z 447[\mathrm{M}-\mathrm{H}]^{-}$. The mass spectrum showed the high abundance of fragments at $\mathrm{m} / \mathrm{z}$ $285[\mathrm{M}-\mathrm{H}-162]^{-}$is due to the loss of a hexose unit. The deprotonated aglycone fragment at $m / z 285$ suggested that it was originated from luteolin or kaempferol. Characteristic fragments at $m / z 175,151$ and 133 confirmed luteolin as aglycone. Thus compound $\mathbf{6}$ was tentatively designated as luteolin $4^{\prime}$-glucoside. ${ }^{105}$ The molecular ion peak at $m / z 567[\mathrm{M}-\mathrm{H}]^{-}$along with the characteristic fragment ion at $m / z 285$ [luteolin- $\mathrm{H}]^{-}$ supports the previously proposed structure. Compound 7 (peak $7)$ was, thus, tentatively identified as neobignonoside [luteolin7-O-(6" $-p$-hydroxybenzoyl- $\beta$-D-glucopyranoside)] from its negative ESI-MS/MS analysis. ${ }^{\mathbf{1 0 6 , 1 0 7}}$ Compound 8 (peak 8) had the molecular ion at $m / z 461[\mathrm{M}-\mathrm{H}]^{-}$. Dissociation of the parent molecular ion at $\mathrm{m} / \mathrm{z} 461$ gave the subsequent fragment ion at $\mathrm{m} / \mathrm{z} 299[\mathrm{M}-\mathrm{H}-162]^{-}$due to the loss of a sugar moiety and secondary peaks at $m / z 165,161,341$ in agreement with the previous report. ${ }^{108}$ Hence compound 8 was identified as $5,2^{\prime}, 6^{\prime}$ trihydroxy-7-methoxyflavone $2^{\prime}-O-\beta$-D-glucopyranoside. Compound 9 (peak 9) ( $\lambda_{\max }$ 196-256-300) was tentatively identified as luteolin 7methyl ether 5- $\beta$-D-glucoside which displayed $[\mathrm{M}-\mathrm{H}]^{-}$at $\mathrm{m} / \mathrm{z} 461$ and mass fragment ion at $\mathrm{m} / \mathrm{z} 299$ [aglycone- $\mathrm{H}]^{-}$, and secondary peaks at $m / z 165,133 .^{109}$ Compound 11 (peak 11) based on its

Table 4 Crystallography data of three compounds isolated from A. nallamalayana

CCDC no.

Identification code

Empirical formula

Formula weight

Temperature/K

Crystal system

Space group

$a / \AA$

$b / \AA$

$c / \AA$

$\alpha /^{\circ}$

$\beta /^{\circ}$

$\gamma /{ }^{\circ}$

Volume $/ \AA^{3}$

$Z$

$\rho_{\text {calc }} \mathrm{g} / \mathrm{cm}^{3}$

$\mu / \mathrm{mm}^{-1}$

$F(000)$

Crystal size $/ \mathrm{mm}^{3}$

Radiation

$2 \Theta$ range for data collection/ ${ }^{\circ}$

Index ranges

Reflections collected Independent reflections

Data/restraints/parameters Goodness-of-fit on $F^{2}$

Final $R$ indexes $[I \geq 2 \sigma(I)]$

Final $R$ indexes [all data] Largest diff. peak/hole/e $\AA^{-3}$ Flack parameter

2072153
$\mathrm{ANM} \_18 \_23 \_$Echioidinin_0m_a
$\mathrm{C}_{16} \mathrm{H}_{12} \mathrm{O}_{5}$
284.26
100
Monoclinic
$P 2_{1} / n$
$7.0308(2)$
$14.1809(4)$
$24.9877(6)$
90
$92.5360(10)$
90
$2488.91(12)$
8
1.517
0.953
1184
$0.75 \times 0.28 \times 0.14$
$\mathrm{CuK} \alpha(\lambda=1.54178)$
7.082 to 133.246
$-8 \leq h \leq 6,-16 \leq k \leq 16$,
$-29 \leq l \leq 29$
37622
$4341\left[R_{\text {int }}=0.0634\right.$,
$\left.R_{\text {sigma }}=0.0354\right]$
$4341 / 0 / 386$
1.113
$R_{1}=0.0463, \mathrm{w} R_{2}=0.1237$
$R_{1}=0.0475, \mathrm{w} R_{2}=0.1248$
$0.28 /-0.27$
$\mathrm{NA}$

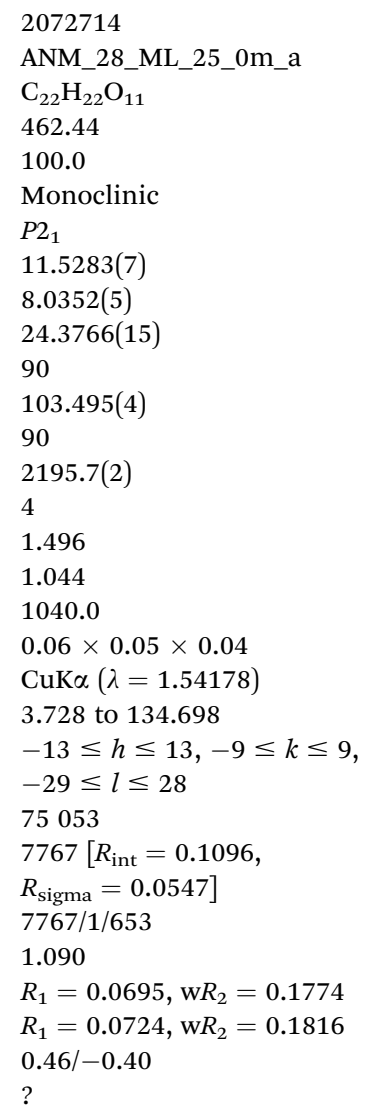


Table 5 NMR data (DMSO- $d_{6},{ }^{1} \mathrm{H} 600 \mathrm{MHz}$ and ${ }^{13} \mathrm{C} 150 \mathrm{MHz}$ ) of compounds isolated from A. nallamalayana

\begin{tabular}{|c|c|c|c|c|c|c|}
\hline \multirow[b]{2}{*}{ Position } & \multicolumn{2}{|l|}{1} & \multicolumn{2}{|l|}{2} & \multicolumn{2}{|l|}{3} \\
\hline & $\delta_{\mathrm{H}}(J$ in $\mathrm{Hz})$ & $\delta_{\mathrm{C}}$ & $\delta_{\mathrm{H}}(J$ in $\mathrm{Hz})$ & $\delta_{\mathrm{C}}$ & $\delta_{\mathrm{H}}(J$ in $\mathrm{Hz})$ & $\delta_{\mathrm{C}}$ \\
\hline 2 & - & 161.99, C & & $161.58, \mathrm{C}$ & - & $162.24, \mathrm{C}$ \\
\hline 3 & $7.11(\mathrm{~s})$ & 109.62, CH & $7.08(\mathrm{~s})$ & 108.79, CH & $6.32(\mathrm{~s})$ & $113.01, \mathrm{CH}$ \\
\hline 4 & - & $182.54, \mathrm{C}$ & - & $182.34, \mathrm{C}$ & - & 182.56, C \\
\hline 5 & - & $161.50, \mathrm{C}$ & - & $156.57, \mathrm{C}$ & - & 161.71, C \\
\hline 6 & $6.37(\mathrm{~d}, J=2.04)$ & $98.36, \mathrm{CH}$ & $6.56(\mathrm{~s})$ & $95.81, \mathrm{CH}$ & $6.39(\mathrm{~d}, J=2.4)$ & 98.35, CH \\
\hline 7 & - & $165.67, \mathrm{C}$ & - & $158.42, \mathrm{C}$ & - & $165.64, \mathrm{C}$ \\
\hline 8 & $6.76(\mathrm{~d}, J=1.5)$ & $93.03, \mathrm{CH}$ & - & $128.40, \mathrm{C}$ & $6.61(\mathrm{~d}, J=2.4)$ & $93.13, \mathrm{CH}$ \\
\hline 9 & - & 157.86, C & - & $148.90, \mathrm{C}$ & - & 158.87, C \\
\hline 10 & - & 105.11, C & - & 103.58, C & - & $105.54, \mathrm{C}$ \\
\hline $1^{\prime}$ & - & 117.52, C & - & $117.13, \mathrm{C}$ & - & $110.69, \mathrm{C}$ \\
\hline $2^{\prime}$ & - & $157.32, \mathrm{C}$ & - & $156.93, \mathrm{C}$ & - & $157.00, \mathrm{C}$ \\
\hline $3^{\prime}$ & $6.99(\mathrm{t}, J=7.514 .94)$ & $117.43, \mathrm{CH}$ & $7.06-7.02(\mathrm{~m})$ & $117.21, \mathrm{CH}$ & $6.73(\mathrm{~d}, J=8.4)$ & $106.24, \mathrm{CH}$ \\
\hline $4^{\prime}$ & $7.40(\mathrm{td}, J=7.12,15.28)$ & 133.41, CH & $7.43(\mathrm{~m})$ & 133.07, CH & $7.28(\mathrm{t}, J=8.4,16.6)$ & $132.74, \mathrm{CH}$ \\
\hline $5^{\prime}$ & $7.07(\mathrm{~d}, J=8.2)$ & $119.85, \mathrm{CH}$ & $7.06-7.02(\mathrm{~m})$ & $119.64, \mathrm{CH}$ & $6.65(\mathrm{~d}, J=8.4)$ & $110.08, \mathrm{CH}$ \\
\hline $6^{\prime}$ & $7.90(\mathrm{dd}, J=1.6,8.02)$ & $128.93, \mathrm{CH}$ & $7.85(\mathrm{dd}, J=7.87,1.0)$ & $128.26, \mathrm{CH}$ & - & $156.77, \mathrm{C}$ \\
\hline $1^{\prime \prime}$ & - & - & - & - & $4.90(\mathrm{~d}, J=7.8)$ & 101.12, CH \\
\hline $2^{\prime \prime}$ & - & - & - & - & $3.06(\mathrm{~m})$ & 73.71, $\mathrm{CH}$ \\
\hline $3^{\prime \prime}$ & - & - & - & - & $3.21(\mathrm{~m})$ & $77.22, \mathrm{CH}$ \\
\hline $4^{\prime \prime}$ & - & - & - & - & $3.11(\mathrm{br} \mathrm{d})$ & $70.13, \mathrm{CH}$ \\
\hline $5^{\prime \prime}$ & - & - & - & - & $3.43(\mathrm{br} \mathrm{d})$ & $77.63, \mathrm{CH}$ \\
\hline $6^{\prime \prime}$ & - & - & - & - & $3.68(\mathrm{br} \mathrm{d}), 3.44(\mathrm{~m})$ & $61.19, \mathrm{CH}_{2}$ \\
\hline $\mathrm{O}-\mathrm{CH}_{3}-7$ & $3.85(\mathrm{~s})$ & $56.48, \mathrm{CH}_{3}$ & $3.89(\mathrm{~s})$ & $56.46, \mathrm{CH}_{3}$ & $3.84(\mathrm{~s})$ & $56.56, \mathrm{CH}_{3}$ \\
\hline $\mathrm{O}-\mathrm{CH}_{3}-8$ & - & - & $3.80(\mathrm{~s})$ & $61.10, \mathrm{CH}_{3}$ & - & - \\
\hline $\mathrm{OH}-5$ & $12.86(\mathrm{~s})$ & - & $12.67(\mathrm{~s})$ & - & $12.92(\mathrm{~s})$ & - \\
\hline $\mathrm{OH}-2^{\prime}$ & $10.91(\mathrm{~s})$ & - & $8.27(\mathrm{~s})$ & - & - & - \\
\hline $\mathrm{OH}-6^{\prime}$ & - & - & - & - & $10.13(\mathrm{~s})$ & - \\
\hline
\end{tabular}

deprotonated molecular ion at $m / z 461[\mathrm{M}-\mathrm{H}]^{-}$and fragments at $m / z 299[\mathrm{M}-\mathrm{H}-\mathrm{Hexose}]^{-}, 283\left[\mathrm{M}-\mathrm{H}-\text { Hexose- } \mathrm{CH}_{3}\right]^{-}, 269[\mathrm{M}-\mathrm{H}-$ $\mathrm{CO}-\mathrm{H}]^{-}$, tetraoxygenated A-ring 161 , and monooxygenated B-ring fragment 117 was characterised as scutellarein 7-methyl ether 6galactoside. ${ }^{110}$ Compound 13 (peak 13), due to loss of glucuronic acid, gave a $[\mathrm{M}-\mathrm{H}]^{-}$ion at $\mathrm{m} / \mathrm{z} 429$ and subsequent fragment ion at $m / z$ 253. Based on fragmentation spectra, accurate mass and previous literature reports, compound 13 was tentatively identified as chrysin-7-glucuronide. ${ }^{111}$ Compound 14 (peak 14) possessed molecular ion $[\mathrm{M}-\mathrm{H}]^{-}$at $m / z$ 461. Furthermore, the fragment ion at $m / z 299$ corresponds to the loss of glucose moiety, indicating the molecular ion of peonidin aglycone. Thus, compound 14 was tentatively identified as peonidin-3-O-galactoside. ${ }^{112} \mathrm{MS} / \mathrm{MS}$ fragmentation spectra of the identified compounds from A. nallamalayana given in ESI Fig. $3 . \dagger$

\subsection{Structure elucidation of chemicals constituents of methanol extract of $A$. nallamalayana}

Three compounds were isolated in various yields from the methanol extract of $A$. nallamalayana. Compound 1 was crystallized with $\mathrm{MeOH}$, which produced yellow needle crystals, $\mathrm{mp}$ 264-265 ${ }^{\circ}$. The negative ion mass spectra showed $[\mathrm{M}-\mathrm{H}]^{-}$peak at $m / z 283.09$, correspondings to molecular formula $\mathrm{C}_{16} \mathrm{H}_{12} \mathrm{O}_{5}$. This was corroborated by the ${ }^{13} \mathrm{C}$-NMR spectrum, which showed signals for all the molecule's twelve carbons. Compound 2 was crystallized with $\mathrm{MeOH}$, which gave the yellow needle-shaped crystals, mp $210-211^{\circ}$. Compound 2 gave $[\mathrm{M}-\mathrm{H}]^{-}$peak at $\mathrm{m} / \mathrm{z}$ 313.12 in its HRMS corresponding to molecular formula $\mathrm{C}_{17} \mathrm{H}_{14} \mathrm{O}_{6}$, which was corroborated by ${ }^{13} \mathrm{C}-\mathrm{NMR}$ spectrum, which showed signals for all the fourteen carbons of the molecule. Compound 3, which was crystallized with $\mathrm{MeOH}$, gave colourless needles, $\mathrm{mp}$ $138-139^{\circ}$ showed $[\mathrm{M}-\mathrm{H}]^{-}$peak at $m / z 461.11$ in its negative ion mass spectra corresponding to molecular formula $\mathrm{C}_{22} \mathrm{H}_{22} \mathrm{O}_{11}$, corroborated by ${ }^{13} \mathrm{C}-\mathrm{NMR}$ spectrum, which showed signals for all the fourteen carbons of the molecule.

The structures of three known compounds were characterised as echioidinin ${ }^{113}$ (compound 1), skullcapflavone $\mathrm{I}^{114}$ (compound 2), and $5,2^{\prime}, 6^{\prime}$-trihydroxy-7-methoxyflavone $\quad 2^{\prime}$-O- $\beta$-D-glucopyranoside ${ }^{108}$ (compound 3) based on their single-crystal X-ray diffraction (XRD) (Table 4) and comparison of their spectral data with literature (Table 5). The crystal structures of echioidinin (CCDC deposition no. 2072153); skullcapflavone I (CCDC deposition no. 2072155), and $5,2^{\prime}, 6^{\prime}$-trihydroxy-7-methoxyflavone $2^{\prime}$ - $O$ - $\beta$-D-glucopyranoside (CCDC deposition no. 2072714) were reported for the first time (Fig. 8). The crystal of compound 3 was twinned and treated accordingly with HKL5 format. The final residual factors or discrepancy indices $\left(R_{1}\right.$ values) of compound 3 was $6.95 \%$ which was due to the limited quality of the data. All crystals' thermal ellipsoid plot was represented in ESI along with the CheckCif alerts (Fig. S5, S11, and S17).†

\subsection{HPLC-UV analysis of methanolic leaf extract of $A$. nallamalayana}

A simple RP HPLC method with a gradient of acetonitrile and water was used for the simultaneous identification of secondary metabolites of $A$. nallamalayana. The HPLC-UV chromatogram of methanolic leaf extract of $A$. nallamalayana showed 13 major 


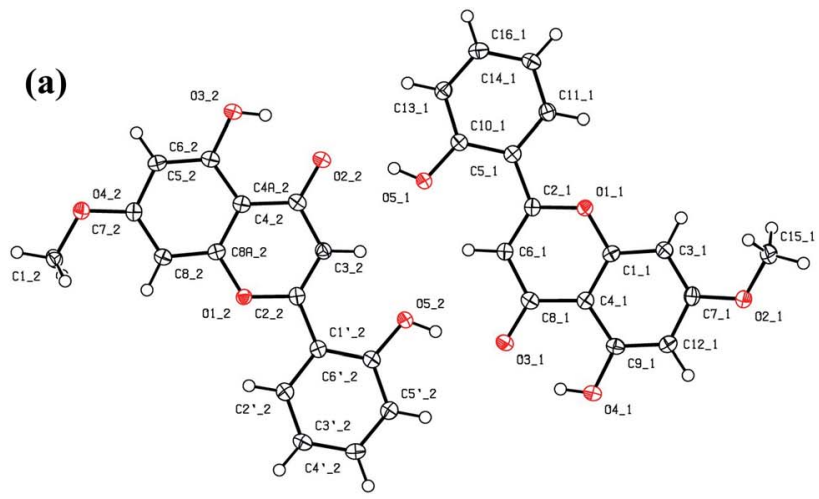

(b)

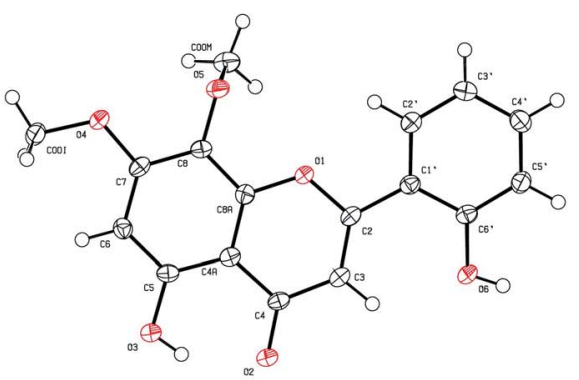

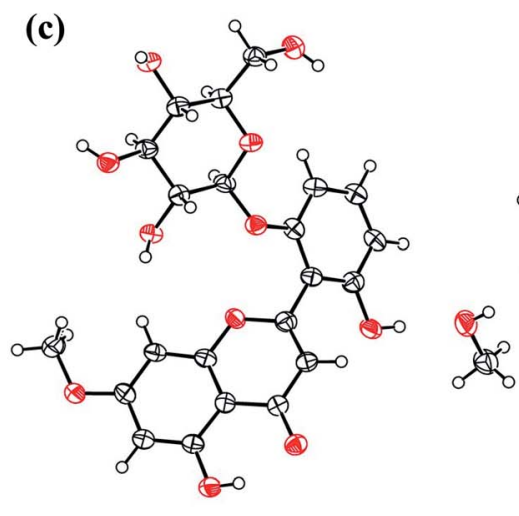

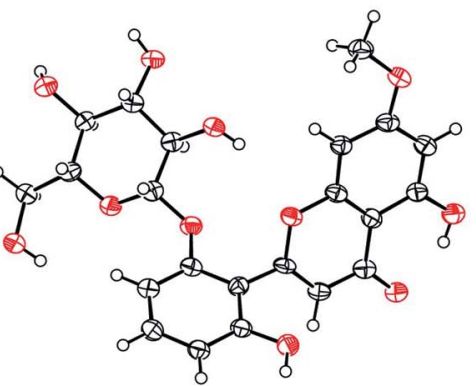<smiles>COc1cc(O)c2c(=O)cc(-c3ccc(F)cc3O)oc2c1</smiles>

(a)<smiles>COc1cc(O)c2c(=O)cc(-c3ccc(F)cc3O)oc2c1OC</smiles>

(b)<smiles>COc1cc(O)c2c(=O)cc(-c3cccc(O)c3O[C@H]3OC(CO)[C@@H](O)[C@H](O)[C@H]3O)oc2c1</smiles>

(c)

Fig. 8 Crystal structures of three compounds isolated from A. nallamalayana. (a) Echioidinin (CCDC deposition no. 2072153); (b) skullcapflavone I (CCDC deposition no. 2072155); and (c) 5,2',6'-trihydroxy-7-methoxyflavone $2^{\prime}$-O- $\beta$-D-glucopyranoside with methanol as solvent molecule (CCDC deposition no. 2072714). 
and minor peaks (Fig. 9). Seven major peaks, peaks 1 and 2, respectively, identified as phenolic acids that correspond to chlorogenic acid $(\lambda=217,240 \mathrm{sh}, 324 \mathrm{~nm}, \mathrm{rt}: 3.08 \mathrm{~min})$, and 3,4di-O-caffeoylquinic acid ( $\lambda=243,303 \mathrm{sh}, 325 \mathrm{~nm}, \mathrm{rt}: 4.29 \mathrm{~min})$. Peaks 3 and 7 were identified as flavonoid glucoside, which corresponded to hispidulin 7-glucoside (homoplantaginin) $(\lambda=$ 226, $334 \mathrm{~nm}$, rt: $15.09 \mathrm{~min})$, and 5,2',6'-trihydroxy-7methoxyflavone $2^{\prime}$ - $O$ - $\beta$-D-glucopyranoside $(\lambda=275,327 \mathrm{~nm}, \mathrm{rt}$ : $30.86 \mathrm{~min})$. Peaks 8,10 , and 11 were identified as flavone derivatives corresponds to oroxylin A $(\lambda=273,321 \mathrm{~nm}$, rt: 38.39 min); skullcapflavone $\mathrm{I}(\lambda=270,320 \mathrm{~nm}$; rt: $47.980 \mathrm{~min})$ and echioidinin $(\lambda=265,335 \mathrm{~nm}$, rt: $48.742 \mathrm{~min})$, respectively. HPLC-UV analysis revealed that flavonoids and phenolics were the main components of methanolic leaf extract of A. nallamalayana, which were also characterised by UPLC-QTOF-MS/MS analysis. Flavonoids are the most studied class of plant's secondary metabolites with well-defined physical and chemical properties. Flavonoids give a characteristic UV absorption pattern, making their UV/PDA spectra very distinctive and UV spectroscopy a preferred analytical tool for identification. ${ }^{\mathbf{1 1 5}}$ Two characteristic bands observed in UV spectra of flavonoids, band I ( $\left.\lambda_{\max } 300-380 \mathrm{~nm}\right)$ is caused by ring B absorption, while band II ( $\left.\lambda_{\max } 240-280 \mathrm{~nm}\right)$ is caused by ring A absorption. These bands' location provides details on the class of flavonoids as well as their substitution pattern; hence, UV spectroscopy has been used as the primary tool for the quantification and

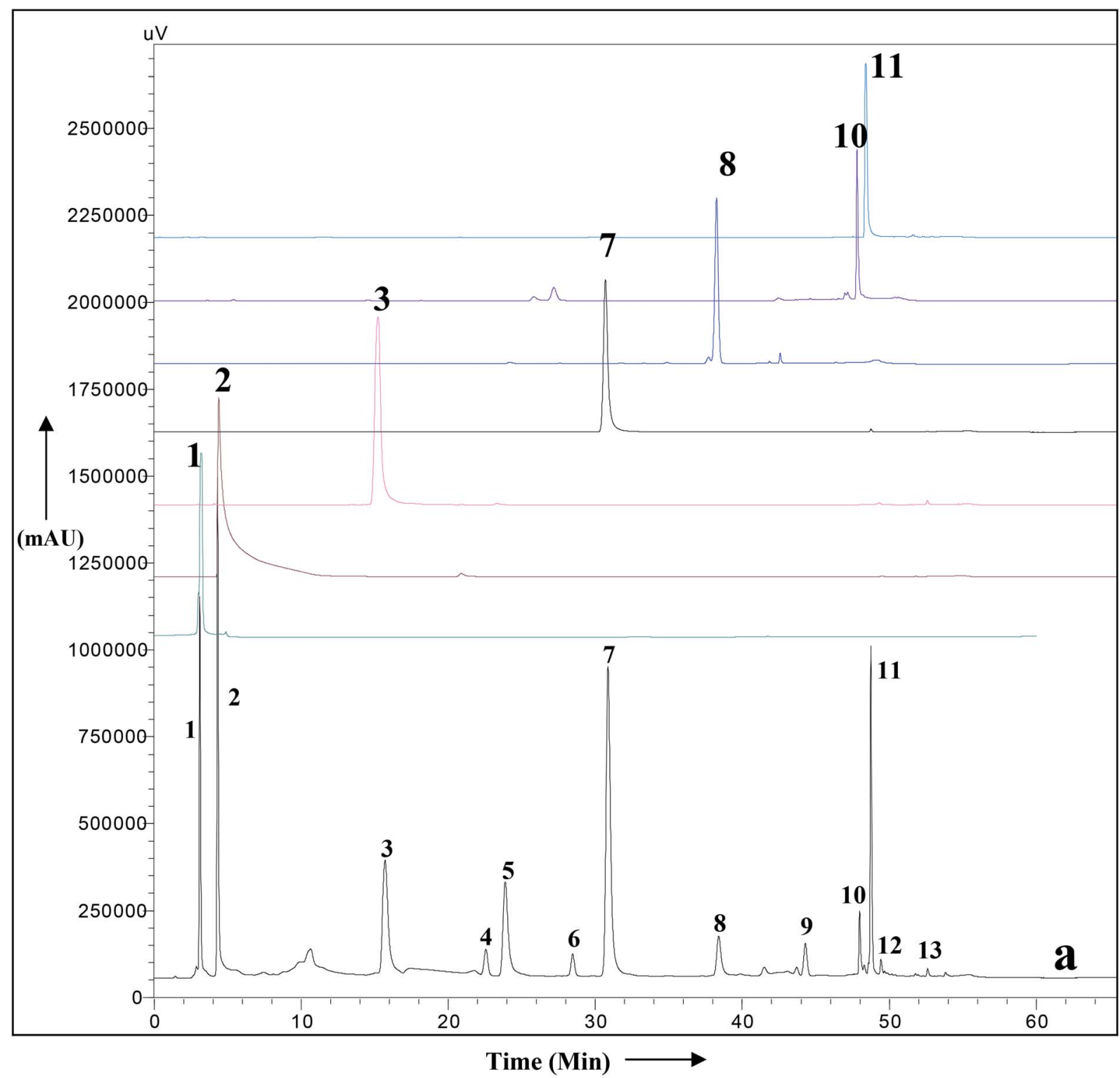

Fig. 9 HPLC-UV chromatogram of the total methanolic extract of $A$. nallamalayana aerial parts (a), and authentic commercial standard/purified compounds: (1) chlorogenic acid; (2) 3,4-di-O-caffeoylquinic acid; (3) hispidulin 7-glucoside (homoplantaginin); (7) 5,2',6'-trihydroxy-7methoxyflavone $2^{\prime}-O-\beta$-D-glucopyranoside; (8) oroxylin A; (10) skullcapflavone I; (11) echioidinin. Mobile phase: water (A) and acetonitrile (B) with a gradient system, i.e., 0-40 min, 0-70\% B; 40-50 min, 70-100\% B; 50-60 min, 100\% B; 60-65 min, 0\% B, flow $1 \mathrm{ml} \mathrm{min}^{-1}$, for other chromatographic conditions, see experimental part. 
identification of flavonoids for years. ${ }^{116}$ All peaks were identified by direct comparison (retention time and UV-spectra) with authentic commercial standards and isolated compounds.

\subsection{Prediction of the in silico biological activity}

3.11.1 In silico anticancer activity prediction using PASS program. In order to mitigate the complexity and expenses of experimental in vivo screening of anticancer agents using tens of millions of natural and synthetic chemical compounds, in silico phenotypic screening methods are required.$^{50}$ We used the successfully reported PASS (Prediction of Activity Spectra for Substances) algorithm to predict the anticancer activity of all the compounds identified from the methanolic extract of $A$. nallamalayana. 20 compounds were analysed by the PASS program for antitumor effects. The results obtained by the PASS prediction are shown in ESI (Table S3). $\dagger$ Among the screened compounds, 17 compounds showed significant probable anticancer/antineoplastic activity $(\mathrm{Pa} \geq 0.9)$, whereas three compounds were inactive $(\mathrm{Pa}<0.9)$. Isorhamnetin 3-glucoside showed the highest Pa values (0.974/0.001), whereas chlorogenic acid showed the minimum Pa value $(0.846 / 0.004)$. The majority of compounds belong to phenolic acids, flavonoids and their glucoside which are well known for their anticancer activities. ${ }^{117-119}$ As evident from the findings, the scores for probable activity $(\mathrm{Pa})$ were very close to 1 , and the scores for probable inactivity (Pi) were very close to 0 , indicating that these compounds are highly likely to be active in the in vitro/in vivo studies.

3.11.2 In silico cell line cytotoxicity prediction using CLCPred tool. CLC-Pred, a well-known tool used in chemoinformatics and medicinal chemistry to predict the in silico cytotoxicity for tumour and non-tumour cell lines, was used to predict the cytotoxicity of the identified compounds. The estimated results that have been presented in Pa values, which is $>0.5$, are probably more active with the predicted cancer cell line. From the 20 compounds selected, 14 compounds showed aspirated outcome, and barely six compounds displayed negative results (Table $\mathrm{S} 4 \dagger$ ). The cytotoxicity represented by the compounds identified from the methanolic extract of $A$. nallamalayana matches the present study and literature survey. ${ }^{119-121}$

\section{Conclusion}

In the present study, the methanolic extract of two Andrographis species, A. nallamalayana and A. paniculata, showed significant cytotoxicity towards three different cancer cell in a dosedependent manner. The cytotoxicity of ANM was nearly four times higher than APM in HCT 116 and HepG2 cells, whereas both extracts showed comparatively similar cytotoxicity in A549 cells and no or very less cytotoxicity in HEK 293 cells. Furthermore, ANM induced cell death involves apoptotic changes and inhibition of migration, ROS generation, up-regulation and down-regulation of main apoptotic markers as seen in HCT 116 cells. Although both species showed promising cytotoxic activity, the comparative phytochemical investigation revealed that both species had different chemical constituents. Both species were found to contain significant quantities of phenolics and flavonoids. Using UPLC-QTOF-MS (HRMS) analysis, andrographolides were identified as the major compounds of A. paniculata. Interestingly, andrographolides were not found in A. nallamalayana.

Further, using the MS/MS fragmentation approach, 20 compounds were characterized/identified from A. nallamalayana; out of 20, 18 compounds were identified for the first time from this species. Three known compounds, echioidinin, skullcapflavone I and 5,2',6'-trihydroxy-7-methoxyflavone $2^{\prime}-O-$ $\beta$-D-glucopyranoside, were isolated from A. nallamalayana and their crystal structures were reported for the first time. Subsequently, seven major compounds were identified in A. nallamalayana by direct comparison (retention time and UV-spectra) with authentic commercial standards and isolated compounds using HPLC-UV analysis. The prediction of anticancer activity using in silico tools also justifies the evaluation of the in vitro cytotoxic activity. Our experimental studies have validated the traditional use of A. nallamalayana and A. paniculata as an anticancer herbal drug. However, more studies are required to explore the role of $A$. nallamalayana in different in vivo cancer models so that it can contribute to the successful treatment of cancer in future.

\section{Author contributions}

Narender Goel: conceptualization, methodology, investigation, writing-original draft. Rahul L. Gajbhiye: conceptualization, methodology, investigation, data curation, software. Moumita Saha: methodology, writing, formal analysis, data curation. Chennuru Nagendra: resources validation. Araveeti Madhusudhana Reddy: resources, validation, review \& editing. V. Ravichandiran: project administration, funding acquisition, review \& editing. Krishna Das Saha: formal analysis, data curation, writing-review \& editing, validation. Parasuraman Jaisankar: supervision, conceptualization, project administration, writing-review \& editing.

\section{Conflicts of interest}

There are no conflicts to declare.

\section{Acknowledgements}

The author NG thanks the Department of Pharmaceuticals, Ministry of Chemicals and Fertilizers, Govt. of India for fellowship. The authors also gratefully acknowledge NIPERKolkata for providing access to the Central Instrumentation Facility (CIF) and CSIR-IICB for funding this project in the form of the Major Laboratory Project (MLP-116). Author AMR thanks the Ministry of Environment, Forests and Climate Change (MoEF \& CC), New Delhi, for assistance in the Lead Botanic Garden at Yogi Vemana University.

\section{References}

1 B. B. Petrovska, Pharmacogn. Rev., 2012, 6, 1-5.

2 C. A. Boopathi, Anc. Sci. Life., 2000, 19(3-4), 164-168. 
3 A. Inta, P. Trisonthi and C. Trisonthi, J. Ethnopharmacol., 2013, 149(1), 344-351.

4 C. Alagesaboopathi, P. Diwakaran and V. S. Ramachandran, Anc. Sci. Life., 1999, 19(1-2), 28-30.

5 A. Okhuarobo, J. Ehizogie Falodun, O. Erharuyi, V. Imieje, A. Falodun and P. Langer, Asian Pac. J. Trop. Dis., 2014, 4(3), 213-222.

6 R. Silambarasan and M. Ayyanar, J. Ethnopharmacol., 2015, 172, 162-178.

7 C. V. Chandrasekaran, A. Gupta and A. Agarwal, J. Ethnopharmacol., 2010, 129(2), 203-207.

8 S. Akbar, Alternative Med. Rev., 2011, 16(1), 66-77.

9 A. Chowdhury, S. K. Biswas, S. Z. Raihan, J. Das and S. Paul, Int. J. Pharmacol., 2012, 8(1), 6-9.

10 S. K. Mishra, N. S. Sangwan and R. S. Sangwan, Rev.: Lit. Arts Am., 2007, 1, 283-298.

11 R. Ajaya Kumar, K. Sridevi, N. Vijaya Kumar, S. Nanduri and S. Rajagopal, J. Ethnopharmacol., 2004, 92(2-3), 291-295.

12 L. Li, G. G. L. Yue, J. K. M. Lee, E. C. W. Wong, K. P. Fung, J. Yu, C. B. S. Lau and P. W. Y. Chiu, Sci. Rep., 2017, 7(1), 1-14.

$13 \mathrm{~K}$. Sheeja and G. Kuttan, Immunopharmacol. Immunotoxicol., 2007, 29(1), 81-93.

14 R. Suzuki, Y. Matsushima, N. Okudaira, H. Sakagami and Y. Shirataki, Anticancer Res., 2016, 36(11), 5931-5935.

15 M. S. Hossain, Z. Urbi, A. Sule and K. M. H. Rahman, Sci. World J., 2014, 2014, 1-28.

16 R. Subramanian, M. Z. Asmawi and A. Sadikun, Phytochem. Rev., 2012, 11(1), 39-75.

17 W. Li, X. Xu, H. Zhang, C. Ma, H. Fong, R. Van Breemen and J. Fitzloff, Chem. Pharm. Bull., 2007, 55(3), 455-458.

$18 \mathrm{C}$. Xu, G. X. Chou, C. H. Wang and Z. T. Wang, Phytochemistry, 1991, 54(5), 1400-1403.

19 C. Xu, G. X. Chou and Z. T. Wang, Fitoterapia, 2010, 81(6), 610-613.

20 L. M. Bhakshu, K. Venkata Ratnam and R. R. Venkata Raju, Indian J. Nat. Prod. Resour., 2016, 7(1), 25-31.

21 U. Quattrocchi, CRC World Dictionary of Medicinal and Poisonous Plants, 2016.

22 V. Ratnam and V. Raju, Indian J. Tradit. Knowl., 2005, 4, 267-270.

23 Y. Padma and R. R. V. Raju, Am. J. PharmTech Res., 2013, 3(1), 8-13.

24 S. Parlapally, N. Cherukupalli, S. R. Bhumireddy, P. Sripadi, R. Anisetti, C. C. Giri, V. R. Khareedu and D. Reddy Vudem, Nat. Prod. Res., 2016, 30, 1256-1261.

25 L. M. Bhakshu, K. Venkata Ratnam and R. R. Venkata Raju, Indian J. Nat. Prod. Resour., 2016, 7, 25-31.

26 G. Purushotham, Y. Padma, Y. Nabiha and R. R. Venkata Raju, 3 Biotech, 2016, 6, 1-11.

27 H. Li, W. Yao, Q. Liu, J. Xu, B. Bao, M. Shan, Y. Cao, F. Cheng, A. Ding and L. Zhang, Molecules, 2017, 22(5), 689.

28 S. Ahmed, D. A. Moni, K. D. Sonawane, K. Y. Paek and A. M. Shohael, J. Biomol. Struct. Dyn., 2021, 39(17), 65536566.

29 R. S. Parulekar and K. D. Sonawane, J. Cell. Biochem., 2018, 119(5), 3936-3944.
30 V. G. Shanmuga Priya, P. Swaminathan, U. M. Muddapur, P. M. Fandilolu, R. S. Parulekar and K. D. Sonawane, Int. J. Pept. Res. Ther., 2019, 25(2), 697-709.

31 R. K. Goel, D. Singh, A. Lagunin and V. Poroikov, Med. Chem. Res., 2011, 20(9), 1509-1514.

32 A. Geronikaki, D. Druzhilovsky, A. Zakharov and V. Poroikov, SAR QSAR Environ. Res., 2008, 19(1-2), 27-38.

33 A. Sadym, A. Lagunin, D. Filimonov and V. Poroikov, $S A R$ QSAR Environ. Res., 2003, 14(5-6), 339-347.

34 A. X. S. Bruker, APEX3 Package, APEX3, SAINT and SADABS, 2016.

35 G. M. Sheldrick, Acta Crystallogr., Sect. A: Found. Crystallogr., 2015, A71, 3-8.

36 G. M. Sheldrick, Acta Crystallogr., Sect. C: Struct. Chem., 2015, C71, 3-8.

37 O. V. Dolomanov, L. J. Bourhis, R. J. Gildea, J. A. K. Howard and H. Puschmann, J. Appl. Crystallogr., 2009, 42, 339-341.

38 A. Mondal, C. Das, M. Corbella, A. Bauzá, A. Frontera, M. Saha, S. Mondal, K. Das Saha and S. K. Chattopadhyay, New J. Chem., 2020, 44(18), 7319-7328.

39 S. Mishra, K. Manna, U. Kayal, M. Saha, S. Chatterjee, D. Chandra, M. Hara, S. Datta, A. Bhaumik and K. Das Saha, RSC Adv., 2020, 10(39), 23148-23164.

40 A. Nandy, S. K. Dey, S. Das, R. N. Munda, J. Dinda and K. D. Saha, Mol. Cancer, 2014, 13(1), 1-14.

41 D. Bose, S. Banerjee, N. Chatterjee, S. Das, M. Saha and K. Das Saha, Toxicol. In Vitro, 2019, 58, 207-214.

42 A. Ali, S. Mishra, S. Kamaal, A. Alarifi, M. Afzal, K. Das Saha and M. Ahmad, Bioorg. Chem., 2021, 106, 104479.

43 L. Zhang, A. S. Ravipati, S. R. Koyyalamudi, S. C. Jeong, N. Reddy, P. T. Smith, J. Bartlett, K. Shanmugam, G. Münch and M. J. Wu, J. Agric. Food Chem., 2011, 59, 12361-12367.

44 C. C. Chang, M. H. Yang, H. M. Wen and J. C. Chern, J. Food Drug Anal., 2002, 10, 178-182.

45 A. Sadym, A. Lagunin, D. Filimonov and V. Poroikov, $S A R$ QSAR Environ. Res., 2003, 14, 339-347.

46 A. Lagunin, A. Stepanchikova, D. Filimonov and V. Poroikov, Bioinformatics, 2000, 16, 747-748.

47 D. A. Filimonov, A. A. Lagunin, T. A. Gloriozova, A. V. Rudik, D. S. Druzhilovskii, P. V. Pogodin and V. V. Poroikov, Chem. Heterocycl. Compd., 2014, 50(3), 444-457.

48 A. Rakib, S. Ahmed, M. A. Islam, A. Haye, S. M. N. Uddin, M. M. N. Uddin, M. K. Hossain, A. Paul and T. Bin Emran, Food Sci. Nutr., 2020, 8(1), 547-556.

49 A. Lagunin, M. Povydysh, D. Ivkin, V. Luzhanin, M. Krasnova, S. Okovityi, A. Nosov, M. Titova, S. Tomilova, D. Filimonov and V. Poroikov, Mol. Inf., 2020, 39(11), 2000093.

50 A. A. Lagunin, V. I. Dubovskaja, A. V. Rudik, P. V. Pogodin, D. S. Druzhilovskiy, T. A. Gloriozova, D. A. Filimonov, N. G. Sastry and V. V. Poroikov, PLoS One, 2018, 13(1), e0191838.

51 S. Rajeshkumar, M. Nagalingam, M. Ponnanikajamideen, M. Vanaja and C. Malarkodi, World J. Pharm. Pharm. Sci., 2015, 4(6), 1667-1675. 
52 P. Sagadevan and S. N. Suresh, Int. J. PharmTech Res., 2015, 7(1), 148-155.

53 M. C. S. Tan, G. Oyong, C. C. Shen and C. Ragasa, J. Nat. Sci., Biol. Med., 2018, 9(2), 201.

54 P. Sagadevan, S. Suresh, S. Rathishkumar, S. Gayathri and D. Eswari, Int. J. Pharm. Life Sci., 2013, 4(9), 2983-2986.

55 A. Goldin, J. M. Venditti, J. S. Macdonald, F. M. Muggia, J. E. Henney and V. T. Devita, Eur. J. Cancer, 1981, 17(2), 129-142.

56 M. R. Grever, S. A. Schepartz and B. A. Chabner, Semin. Oncol., 2021, 116, 105334.

57 M. Redza-Dutordoir and D. A. Averill-Bates, Biochim. Biophys. Acta, Mol. Cell Res., 2016, 1863(12), 2977-2992.

58 S. Elmore, Toxicol. Pathol., 2007, 35, 495-516.

59 E. Brauchle, S. Thude, S. Y. Brucker and K. SchenkeLayland, Sci. Rep., 2014, 4(1), 1-9.

60 L. Ming, P. Wang, A. Bank, J. Yu and L. Zhang, J. Biol. Chem., 2006, 281, 16034-16042.

$61 \mathrm{~J} . \mathrm{Yu}$, L. Zhang, P. M. Hwang, K. W. Kinzler and B. Vogelstein, Mol. Cell, 2001, 7, 673-682.

62 J. Yu, Z. Wang, K. W. Kinzler, B. Vogelstein and L. Zhang, Proc. Natl. Acad. Sci. U. S. A., 2003, 100, 1931-1936.

63 C. Soldani and A. I. Scovassi, Apoptosis, 2002, 7(4), 321-328.

64 G. V. Chaitanya, J. S. Alexander and P. P. Babu, Cell Commun. Signaling, 2010, 8(1), 1-11.

65 J. W. Kim, K. Kim, K. Kang and C. O. Joe, J. Biol. Chem., 2000, 272(11), 8121-8125.

66 R. D. Castellone, N. R. Leffler, L. Dong and L. V. Yang, Cancer Lett., 2011, 312, 197-208.

67 P. S. Steeg, Nat. Med., 2006, 12, 895-904.

68 M. Harishkumar, Y. Masatoshi, S. Hiroshi, I. Tsuyomu and M. Masugi, BioMed Res. Int., 2013, 2013, 8.

69 N. U. Nair, A. Das, V. M. Rogkoti, M. Fokkelman, R. Marcotte, C. G. de Jong, E. Koedoot, J. S. Lee, I. Meilijson, S. Hannenhalli, B. G. Neel, B. van de Water, S. E. Le Dévédec and E. Ruppin, Sci. Rep., 2019, 9(1), 1-12.

70 Y. Wan, D. Tamuly, P. B. Allen, Y. T. Kim, R. Bachoo, A. D. Ellington and S. M. Iqbal, Biomed. Microdevices, 2013, 15(4), 635-643.

71 S. Geetha, M. S. Ram, S. S. Mongia, V. Singh, G. Ilavazhagan and R. C. Sawhney, J. Ethnopharmacol., 2003, 87, 247-251.

72 H. M. Chen, Y. C. Wu, Y. C. Chia, F. R. Chang, H. K. Hsu, Y. C. Hsieh, C. C. Chen and S. S. Yuan, Cancer Lett., 2009, 286(2), 161-171.

73 Y. J. Lee, P. H. Liao, W. K. Chen and C. C. Yang, Cancer Lett., 2000, 153(1-2), 51-56.

74 G. W. Yang, J. S. Jiang and W. Q. Lu, Int. J. Mol. Sci., 2015, 16(10), 24011-24031.

75 M. Abotaleb, S. M. Samuel, E. Varghese, S. Varghese, P. Kubatka, A. Liskova and D. Büsselberg, Cancers, 2019, 11(1), 28.

76 S. M. Kuo, Crit. Rev. Oncog., 1997, 8(1), 47-69.

77 N. J. Kang, K. W. Lee, B. H. Kim, A. M. Bode, H. J. Lee, Y. S. Heo, L. Boardman, P. Limburg, H. J. Lee and Z. Dong, Carcinogenesis, 2011, 32(6), 921-928.

78 S. Jin, Q. Y. Zhang, X. M. Kang, J. X. Wang and W. H. Zhao, Ann. Oncol., 2010, 21(2), 263-268.
79 S. Kaushik, H. Shyam, S. Agarwal, R. Sharma, T. C. Nag, A. K. Dwivedi and A. K. Balapure, Life Sci., 2019, 239, 117073.

80 S. K. Jaganathan, E. Supriyanto and M. Mandal, World J. Gastroenterol., 2013, 19(43), 7726.

81 S. Sambantham, M. Radha, A. Paramasivam, B. Anandan, R. Malathi, S. R. Chandra and G. Jayaraman, Asian Pac. J. Cancer Prev., 2013, 14(7), 4347-4352.

82 M. C. Yin, C. C. Lin, H. C. Wu, S. M. Tsao and C. K. Hsu, J. Agric. Food Chem., 2009, 57(14), 6468-6473.

83 X. Zhang, D. Lin, R. Jiang, H. Li, J. Wan and H. Li, Oncol. Rep., 2016, 36(1), 271-278.

84 W. Lim, S. Park, F. W. Bazer and G. Song, J. Cell. Biochem., 2017, 118(5), 1118-1131.

85 S. M. Hadi, S. F. Asad, S. Singh and A. Ahmad, IUBMB Life, 2000, 50(3), 167-171.

86 A. Link, F. Balaguer and A. Goel, Biochem. Pharmacol., 2010, 80(12), 1771-1792.

87 C. G. Fraga, M. Galleano, S. V. Verstraeten and P. I. Oteiza, Mol. Aspects Med., 2010, 31(6), 435-445.

88 H. S. Youn, J. Y. Lee, S. I. Saitoh, K. Miyake, K. W. Kang, Y. J. Choi and D. H. Hwang, Biochem. Pharmacol., 2006, 72(7), 850-859.

89 M. Valko, D. Leibfritz, J. Moncol, M. T. D. Cronin, M. Mazur and J. Telser, Int. J. Biochem. Cell Biol., 2007, 39, 44-84.

90 M. Ye, W. Z. Yang, K. Di Liu, X. Qiao, B. J. Li, J. Cheng, J. Feng, D. A. Guo and Y. Y. Zhao, J. Pharm. Anal., 2012, 2, 35-42.

91 J. Y. Zhang, Q. Zhang, N. Li, Z. J. Wang, J. Q. Lu and Y. J. Qiao, Talanta, 2013, 104, 1-9.

92 M. N. Clifford, S. Knight and N. Kuhnert, J. Agric. Food Chem., 2005, 53, 3821-3832.

93 K. Schütz, D. Kammerer, R. Carle and A. Schieber, J. Agric. Food Chem., 2004, 52, 4090-4096.

94 M. N. Clifford, K. L. Johnston, S. Knight and N. Kuhnert, J. Agric. Food Chem., 2003, 51, 2900-2911.

95 H. Sun, M. Liu, Z. Lin, H. Jiang, Y. Niu, H. Wang and S. Chen, J. Pharm. Biomed. Anal., 2015, 115, 86-106.

96 L. Z. Wu, X. P. Zhang, X. D. Xu, Q. X. Zheng, J. S. Yang and W. L. Ding, J. Pharm. Biomed. Anal., 2013, 75, 55-63.

97 A. G. Damu, B. Jayaprakasam, K. V. Rao and D. Gunasekar, Phytochemistry, 1998, 49(6), 1811-1813.

98 W. Wu, C. Yan, L. Li, Z. Liu and S. Liu, J. Chromatogr. A, 2004, 1047, 213-220.

99 Y. Wang, L. Yang, Y. Q. He, C. H. Wang, E. W. Welbeck, S. W. A. Bligh and Z. T. Wang, Rapid Commun. Mass Spectrom., 2008, 22(12), 1767-1778.

100 M. J. Simirgiotis, J. Benites, C. Areche and B. Sepu, Molecules, 2015, 20, 11490-11507.

101 J. Han, M. Ye, M. Xu, J. Sun, B. Wang and D. Guo, J. Chromatogr. B: Anal. Technol. Biomed. Life Sci., 2007, 848(2), 355-362.

102 U. Justesen, J. Mass Spectrom., 2001, 36, 169-178.

103 A. Schieber, P. Keller, P. Streker, I. Klaiber and R. Carle, Phytochem. Anal., 2002, 13, 87-94.

104 M. E. Cuvelier, H. Richard and C. Berset, JAOCS, J. Am. Oil Chem. Soc., 1996, 73, 645-652. 
105 Z. H. Li, H. Guo, W. Bin Xu, J. Ge, X. Li, M. Alimu and D. J. He, J. Chromatogr. Sci., 2016, 54, 805-810.

106 H. S. Manal and S. A. Manal, J. Med. Plants Res., 2014, 8, 1-5.

107 S. Yannai, Dictionary of food compounds with CD-ROM: additives, flavors, and ingredients, Chapman \& Hall/CRC, Boca Raton, 2004, p. 41, http://www.chemlibnetbase.com/ ejournals/books/book_km.asp?id=5851.

108 A. G. Damu, B. Jayaprakasam and D. Gunasekar, J. Asian Nat. Prod. Res., 1998, 1, 133-138.

109 A. Ulubelen, R. Bucker and T. J. Mabry, Phytochemistry, 1982, 21, 801-803.

110 J. B. Harborne and C. A. Williams, Z. Naturforsch. Sect. CJ. Biosci., 1984, 39, 18-23.

111 M. Nurul Islam, F. Downey and C. Ng, Acta Chromatogr., 2013, 25, 555-569.

112 A. Brito, C. Areche, B. Sepúlveda, E. J. Kennelly and M. J. Simirgiotis, Molecules, 2014, 19, 10936-10955.
113 A. Mohammed, K. K. Chiruvella, Y. K. Rao, M. Geethangili, S. C. Raghavan and R. G. Ghanta, PLoS One, 2015, 10(10), e0141154.

114 M. Takido, K. Yasukawa, S. Matsuura and M. Iinuma, Yakugaku Zasshi, 1979, 99(4), 443-444.

115 M. Stefova, T. Stafilov and S. Kulevanova, in Encyclopedia of Chromatography, 2020.

116 E. Graf, Arch. Pharm., 1971, 304, 715.

117 D. M. Kopustinskiene, V. Jakstas, A. Savickas and J. Bernatoniene, Nutrients, 2020, 12(2), 457.

118 K. W. J. Wahle, I. Brown, D. Rotondo and S. D. Heys, Adv. Exp. Med. Biol., 2010, 36-51.

119 C. Kanadaswami, L. T. Lee, P. P. H. Lee, J. J. Hwang, F. C. Ke, Y. T. Huang and M. T. Lee, In Vivo, 2005, 19(5), 895-909.

120 K. Sak, Pharmacogn. Rev., 2014, 8, 122-146.

121 N. P. Reddy, B. A. K. Reddy, D. Gunasekar, A. Blond, B. Bodo and R. V. Raju, Nat. Prod. Commun., 2007, 2(5), 575-578. 